\title{
Use of Engineered Soils and Other Site Modifications for Low-Level Radioactive Waste Disposal
}

\author{
IT Corporation \\ Albuquerque, NM
}

Published August 1994

Prepared for EG\&G Idaho, Inc. Under Subcontract No. C92170252002 and for the

U.S. Department of Energy

Assistant Secretary for Environmental Management

Under DOE Idaho Field Office

Contract DE-AC07-761D01570 



\section{DISCLAIMER}

This report was prepared as an account of work sponsored by an agency of the United States Government. Neither the United States Government nor any agency thereof, nor any of their employees, make any warranty, express or implied, or assumes any legal liability or responsibility for the accuracy, completeness, or usefulness of any information, apparatus, product, or process disclosed, or represents that its use would not infringe privately owned rights. Reference herein to any specific commercial product, process, or service by trade name, trademark, manufacturer, or otherwise does not necessarily constitute or imply its endorsement, recommendation, or favoring by the United States Government or any agency thereof. The views and opinions of authors expressed herein do not necessarily state or reflect those of the United States Government or any agency thereof. 


\section{DISCLAIMER}

Portions of this document may be illegible in electronic image products. Images are produced from the best available original document. 


\section{ABSTRACT}

The U.S. Nuclear Regulatory Commission regulation in Title 10, Code of Federal Regulations, Part 61 (10 CFR 61) requires that low-level radioactive waste (LLW) disposal facilities be designed to minimize contact between waste and infiltrating water through the use of site design features. The purpose of this investigation is to identify engineered barriers and evaluate their ability to enhance the long-term performance of an LLW disposal facility. Previously used barriers such as concrete overpacks, vaults, backfill, and engineered soil covers, are evaluated as well as state-of-the-art barriers, including an engineered sorptive soil layer underlying a facility and an advanced design soil cover incorporating a double-capillary layer. The purpose of this investigation is also to provide information in incorporating or excluding specific engineered barriers as part of new disposal facility designs.

Evaluations are performed using performance assessment modeling techniques to calculate dose reduction factors that quantify the relative improvements in long-term performance offered by these engineered barriers. A generic reference disposal facility design that incorporates the minimum site design features required by 10 CFR 61 is used as a baseline for comparing the improvements in longterm performance offered by designs incorporating engineered barriers in generic arid and humid environments.

These evaluations simulate water infiltration through the facility, waste leaching, radionuclide transport through the facility, and decay and ingrowth. They also calculate a maximum (peak annual) dose for each disposal system design. A relative dose reduction factor, defined as the ratio of the maximum dose for an enhanced design to that of the maximum dose for the reference design is calculated for each design evaluated. These relative performance measures indicate the amount of additional isolation that is provided by each of the engineered modifications.

The results of this investigation are presented for concrete overpacks, concrete vaults, sorptive backfill, sorptive engineered soil underlying the facility, and sloped engineered soil covers using a single-capillary barrier and a double-capillary barrier. Designs using combinations of barriers are also evaluated. These designs include a vault plus overpacks, sorptive backfill plus overpacks, and overpack with vault plus sorptive backfill, underlying sorptive soil, and engineered soil cover. 


\section{EXECUTIVE SUMMARY}

The U.S. Nuclear Regulatory Commission (NRC) regulation Title 10, Code of Federal Regulations (CFR), Part 61 (10 CFR 61) requires that low-level waste radioactive (LLW) disposal facilities be designed to minimize contact between waste and infiltrating water through the use of site design features that should maintain their effectiveness for a prolonged period without the need for active maintenance. The purpose of this investigation is to identify and evaluate the use of engineered soils and other potential barriers or site modifications that may be used to enhance the near-field isolation characteristics of an LLW disposal facility. Previously used barriers (such as concrete overpacks, vaults, backfill, and engineered soil covers) are evaluated, as well as state-of-theart barriers, including an engineered sorptive soil layer underlying the facility and an advanced design soil cover incorporating a double-capillary layer. The results of these analyses can be used as information in incorporating or excluding specific engineered barriers as part of new disposal facility designs.

An evaluation of the isolation enhancements provided by these engineered barriers is provided based on flow and transport modeling of the disposal system. Evaluations are performed using performance assessment modeling techniques to ealculate dose reduction factors, which quantify the relative improvements in long-term performance offered by these engineered barriers.

A generic reference disposal facility design has been developed that incorporates only the bare minimum site design features required by 10 CFR 61 . This design serves as a baseline for comparing the improvements in long-term performance offered by designs incorporating engineered barriers relative to the reference design.

Two generic disposal facility sites are defined-one in an arid environment and one in a humid environment. Flow modeling within the disposal facility is performed using the Variably Saturated 2-Dimensional Flow and Transport (VS2DT) code to obtain Darcy velocity and moisture content values under steady-state conditions for a given disposal system at each of the two sites. For modifications involving concrete engineered barriers (overpacks and vaults), the flow modeling simulates the conditions following failure of the barriers. Measured infiltration rates for generic arid and humid sites are used as input for the VS2DT code. The disposal facility flow characteristics are estimated by VS2DT, based on the backfill and waste form hydrologic properties. Predicted flow results are passed to the Disposal Unit Source Term (DUST) code to derive the time-dependent flux of each radionuclide leaving the bottom of the engineered structure expressed in units of curies/yr.

Decay of the original inventory and ingrowth of daughter products are accounted for, and the resulting radionuclide fluxes are then multiplied by activity-to-dose conversion factors (based on the latest values in $10 \mathrm{CFR} 20$ ) to obtain dose profiles for each radionuclide. These individual timedependent radionuclide dose profiles are then summed over all nuclides to derive a total dose profile (dose versus time), which is then used to identify the maximum (peak annual) dose for a given disposal system design.

A relative dose reduction factor, defined as the ratio of the maximum dose for an enhanced design to that of the maximum dose for the reference design, is calculated for each design. These relative performance measures provide an indicator of the amount of additional isolation provided by each of the engineered modifications. 
Evaluation of the performance of designs incorporating concrete vaults and/or concrete overpacks show relative dose reductions of 10 to $15 \%$ at most, because they can only be relied on to provide complete containment for a few hundred to 1,000 or 2,000 years. A sorbing layer of engineered soil underlying the facility provides only slight dose reduction at best, and under some conditions can actually increase dose by allowing the buildup of daughter products from the decay of ${ }^{232} \mathrm{Th}$ and ${ }^{238} \mathrm{U}$ before release.

A sloped engineered soil cover designed to divert infiltrating water is predicted to be quite effective, providing a 2 to 3 order of magnitude decrease in dose. The only drawback to reliance on this design element to meet the performance objectives is that it must remain effective in diverting a significant percentage of infiltrating water for a significant period of time. This longevity may be difficult to demonstrate because the cover may be subject to erosion over this time scale.

Sorptive backfill is predicted to reduce doses by a factor of 3 to 4 orders of magnitude, which is a factor of 10 more effective than a sloped engineered soil cover. Sorptive backfill can be designed to be chemically stable and, because the backfill surrounds the waste, would only be subject to erosion if the waste itself eroded. 


\section{CONTENTS}

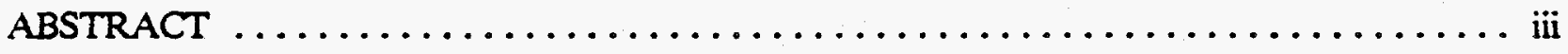

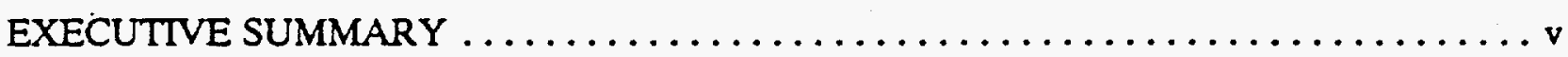

ACRONYMS/ABBREVIATIONS $\ldots \ldots \ldots \ldots \ldots \ldots \ldots \ldots \ldots \ldots \ldots \ldots \ldots \ldots \ldots \ldots \ldots$

1. INTRODUCTION $\ldots \ldots \ldots \ldots \ldots \ldots \ldots \ldots \ldots \ldots \ldots \ldots \ldots \ldots \ldots \ldots \ldots \ldots \ldots$

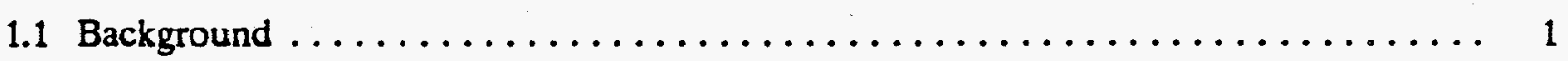

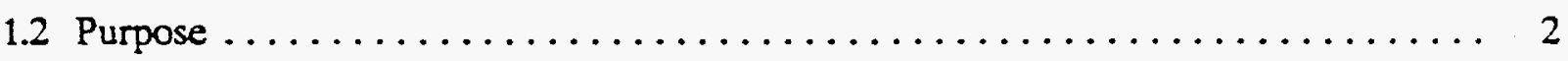

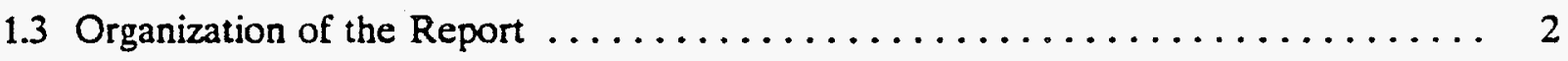

2. GENERAL STUDY METHODOLOGY AND ASSUMPTIONS $\ldots \ldots \ldots \ldots \ldots \ldots$

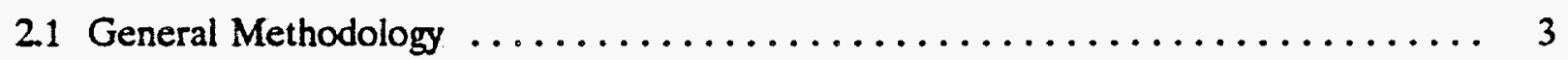

2.1.1 Infiltration of Water Through the Disposal Facility ........... 4

2.1.2 Degradation of Engineered Barriers and Access of Water to the Waste Form .............................. 8

2.1.3 Leaching of Contaminants from the Waste Form $\ldots \ldots \ldots \ldots \ldots \ldots$

2.1.4 Transport of Contaminants to the Disposal Facility Boundary ....... 8

21.5 Adsorption of Radionuclides ...................... 9

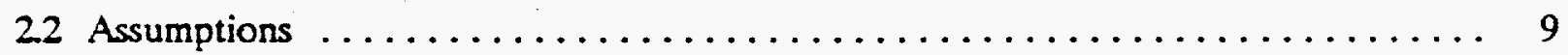

2.2.1 Identification of Representative LLW Radionuclide Inventory ...... 9

2.2.2 Definition of a Reference Waste Volume ................ 11

23 Implementation of Evaluation Methodology $\ldots \ldots \ldots \ldots \ldots \ldots \ldots \ldots \ldots \ldots$

2.3.1 Rationale for the Selection of Codes for Use in the Effectiveness

Evaluations ................................ 11

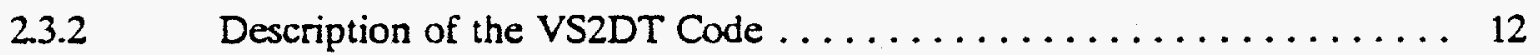

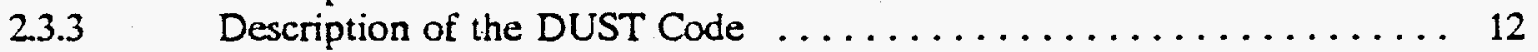

2.3.4 Description of the DECAY Program $\ldots \ldots \ldots \ldots \ldots \ldots \ldots \ldots \ldots$

2.3.5 Description of the DOSE Program ................... 14

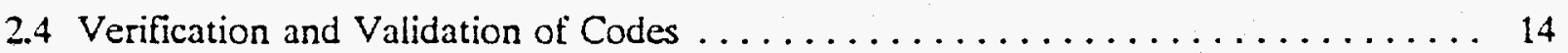

2.4.1 Verification and Validation of VS2DT $\ldots \ldots \ldots \ldots \ldots \ldots \ldots \ldots \ldots$

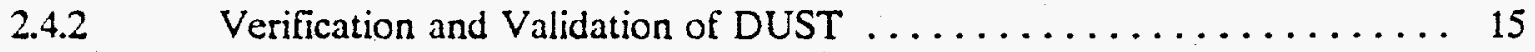

2.4.3 Verification and Validation of DECAY $\ldots \ldots \ldots \ldots \ldots \ldots \ldots \ldots$

2.4.4 Verification and Validation of DOSE $\ldots \ldots \ldots \ldots \ldots \ldots \ldots \ldots$ 
3. GENERIC SITE AND FACILITY DESCRIPTION $\ldots \ldots \ldots \ldots \ldots \ldots \ldots \ldots \ldots$

3.1 Regulatory Guidance on LLW Disposal Facility Design $\ldots \ldots \ldots \ldots \ldots \ldots$

3.2 Reference Facility Design $\ldots \ldots \ldots \ldots \ldots \ldots \ldots \ldots \ldots \ldots \ldots \ldots \ldots \ldots$

4. PRESENT PRACTICES OF USING ENGINEERED SOILS

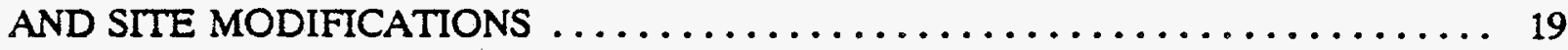

4.1 Engineered Soil Cover/Cap System $\ldots \ldots \ldots \ldots \ldots \ldots \ldots \ldots \ldots \ldots \ldots \ldots$

4.2 Backfill $\ldots \ldots \ldots \ldots \ldots \ldots \ldots \ldots \ldots \ldots \ldots \ldots \ldots \ldots \ldots \ldots \ldots \ldots \ldots \ldots \ldots \ldots \ldots, 22$

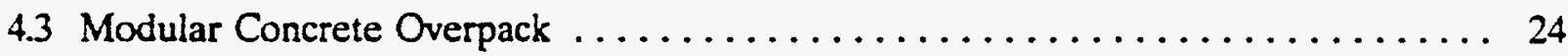

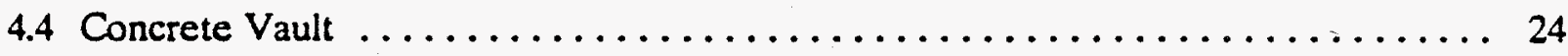

5. IDENTIFICATION OF ADDITIONAL POTENTIAL SOILS AND

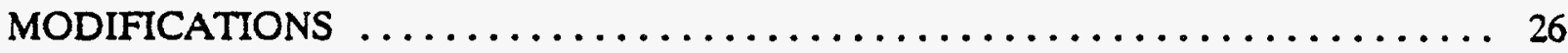

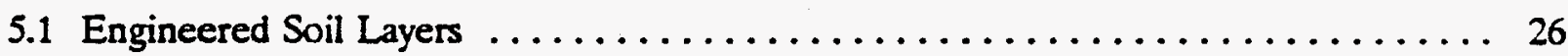

5.2 Engineered Soil Cover with Double-Capillary Barrier $\ldots \ldots \ldots \ldots \ldots \ldots \ldots . \ldots . \ldots 27$

6. DEGREE OF ISOLATION ENHANCEMENT OF EACH IDENTIFIED

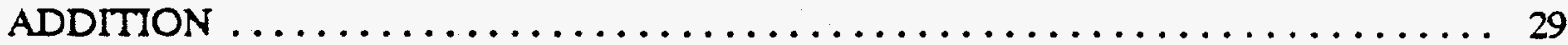

6.1 Evaluation of the Effectiveness of Concrete Barriers ................. 29

6.2 Evaluation of the Effectiveness of Sorptive Backfill $\ldots \ldots \ldots \ldots \ldots \ldots \ldots \ldots$

6.3 Evaluation of the Effectiveness of Designs Incorporating Sorptive Backfill and Concrete

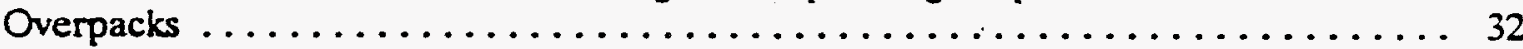

6.4 Evaluation of the Effectiveness of a Sorptive Engineered Soil Beneath

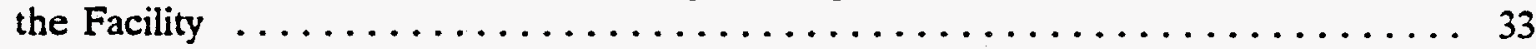

6.5 Evaluation of the Effectiveness of Engineered Soil Cover with a Single-Capillary Barrier $\ldots \ldots \ldots \ldots \ldots \ldots \ldots \ldots \ldots \ldots \ldots \ldots \ldots \ldots \ldots \ldots \ldots$

6.6 Evaluation of the Effectiveness of an Engineered Soil Cover with a Double-Capillary Barrier

6.7 Evaluation of the Performance of a Facility Using a Sloped Engineered Soil Cover, Sorptive Backfill, Underlying Sorptive Soil, Vault, and Overpacks ..................................... 34

7. LOGISTICS AND INCREASED COST OF EACH IDENTIFIED ADDITION ..... 35

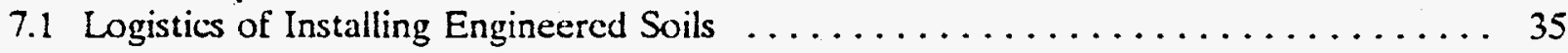


7.2 Incremental Costs of Engineered Barriers . . . . . . . . . . . . . 36

8. SUMMARY AND CONCLUSIONS $\ldots \ldots \ldots \ldots \ldots \ldots \ldots \ldots \ldots \ldots \ldots \ldots$

8.1 Performance of the Reference Design $\ldots \ldots \ldots \ldots \ldots \ldots \ldots \ldots \ldots$

8.2 Performance of Concrete Vaults and Overpacks $\ldots \ldots \ldots \ldots \ldots \ldots \ldots$

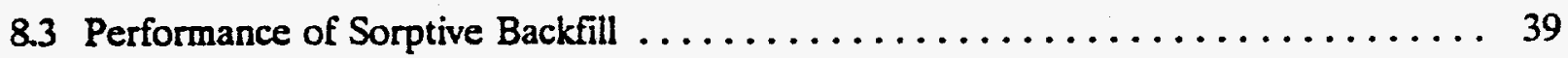

8.4 Performance of Sorptive Soil Layer Underlying Facility . . . . . . . . . . . . 39

8.5 Performance of Engineered Soil Covers $\ldots \ldots \ldots \ldots \ldots \ldots \ldots \ldots \ldots$

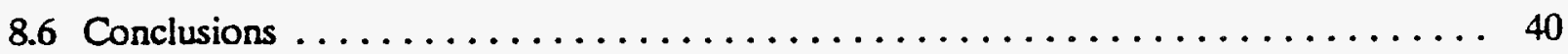

9. REFERENCES $\ldots \ldots \ldots \ldots \ldots \ldots \ldots \ldots \ldots \ldots \ldots \ldots \ldots \ldots \ldots \ldots \ldots \ldots$

Appendix A-Screening of Radionuclides $\ldots \ldots \ldots \ldots \ldots \ldots \ldots \ldots \ldots \ldots \ldots \ldots \ldots$

FIGURES

2-1. Facility design, single-capillary barrier $\ldots \ldots \ldots \ldots \ldots \ldots \ldots \ldots \ldots \ldots \ldots$

3-1. Reference design $\ldots \ldots \ldots \ldots \ldots \ldots \ldots \ldots \ldots \ldots \ldots \ldots \ldots \ldots \ldots \ldots$

5-1. Facility design, double-capillary barrier $\ldots \ldots \ldots \ldots \ldots \ldots \ldots \ldots \ldots \ldots$

6-1. Relative dose reduction factor as a function of concrete failure time $\ldots \ldots \ldots \ldots . \ldots 31$

\section{TABLES}

2-1. Unsaturated hydraulic properties of the flow-model layers $\ldots \ldots \ldots \ldots \ldots \ldots$

2-2. Adsorption coefficients $\left(K_{d}\right)$ for the backfill and sorptive engineered soil layer ...... 9

2-3. Average radionuclide concentrations in disposed commercial LLW $\ldots \ldots \ldots 10$

2-4. Volumes of waste to be disposed by compact disposal site $\ldots \ldots \ldots \ldots \ldots \ldots$

4-1. Summary of low-level waste disposal facility design features-compact states $\ldots \ldots \ldots 20$

6-1. Matrix of engineered soils and other site modifications evaluated . . . . . . . 29

6-2. Effects of concrete barrier failure time on relative dose reduction factor $\ldots \ldots \ldots 31$

6-3. Effects of sorbing backfill on relative dose reduction factors $\ldots \ldots \ldots \ldots \ldots$ 
6-4. Relative performance of a disposal facility incorporating overpacks and sorbing

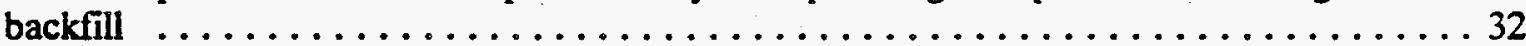

6-5. Relative performance of a disposal facility incorporating sorbing engineered soil beneath the facility . . . . . . . . . . . . . . . . . . . . . . . . 33

6-6. Relative performance of a disposal facility incorporating a sloped engineered soil cover

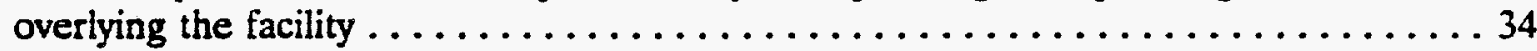

6-7. Relative performance of a disposal facility incorporating a sloped engineered soil cover, sorptive backfill, underlying sorptive soil, vault, and overpacks ........ 34

7-1. Incremental capital and installation costs of engineered barriers relative to reference earth mounded shallow land disposal design $\ldots \ldots \ldots \ldots \ldots \ldots \ldots . \ldots 37$

8-1. Relative dose reduction factors (RDRF) for LLW disposal facility designs at

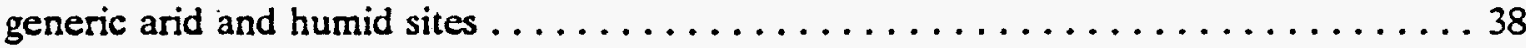




\section{ACRONYMS/ABBREVIATIONS}

ASTM

BLT

CFR

$\mathrm{Ci} / \mathrm{m}^{3}$

DOE

DUST

EPA

FD

HDPE

IDB

LLW

MCMC

NRC

PA

QA/QC

RD

RDRF

SNLNM

USGS

VS2DT
American Society for Testing and Materials

Breach, Leach, and Transport

Code of Federal Regulations

curies per cubic meter

U.S. Department of Energy

Disposal Unit Source Term

U.S. Environmental Protection Agency

finite difference

high-density polyethylene

Integrated Data Base

low-level radioactive waste

Multi-Cell Mixing Cascade

U.S. Nuclear Regulatory Commission

performance assessment

quality assurance/quality control

reference design

relative dose reduction factor

Sandia National Laboratories/New Mexico

United States Geological Survey

Variably Saturated 2-Dimensional Flow and Transport 


\section{Use of Engineered Soils and Other Site Modifications For Low-Level Radioactive Waste Disposal .}

\section{Preliminary Draft Report}

\section{INTRODUCTION}

This section provides the background and purpose of the study and describes the organization of the report.

\subsection{Background}

The Low-Level Radioactive Waste Policy Act of 1980 (the Act) set guidelines for the formation of interstate agreements, or compacts, for the purpose of licensing, constructing, and operating regional low-level radioactive waste (LLW) disposal facilities. The Act authorized the Agreement States to evaluate the suitability of proposed sites and facility designs, provided that the evaluation criteria are compatible with the U.S. Nuclear Regulatory Commission (NRC) regulation cited in Title 10, Code of Federal Regulations (CFR), Part 61, (10 CFR 61) entitled "Licensing Requirements for Land Disposal of Radioactive Waste" (CFR 1990).

The NRC regulation requires that LLW disposal facilities be designed to minimize contact between the waste and infiltrating water through the use of site design features that should maintain their effectiveness for prolonged periods without the need for active maintenance. More specifically, the regulation contains the following functional requirements that relate to the use of engineered soils and site modifications:

- Minimizing infiltration of water into disposal units

- Ensuring the integrity of disposal unit covers

- Providing the structural stability of backfill,-wastes, and covers

- Minimizing contact of waste with standing water (bathtub effect)

- Providing adequate site drainage during operations and after closure

- Minimizing the need for long-term maintenance

- Providing a barrier against inadvertent intrusion.

In the past, commercial LLW disposal facilities have used soil excavated during construction of a trench or cell for construction of a simple mound or cover. Although these soils did reduce infiltration into the trench to some extent, the covers were not engineered to minimize hydraulic conductivity or to provide a mechanism to collect and remove infiltrating moisture.

Current designs are based on the concept of a sloped multilayered cover of natural earthen materials, including contrasting layers of topsoil, rip-rap, clay, sand, and gravel. Some current designs also include manmade layers, such as flexible membrane liners, geosynthetic filter layers, and geosynthetic drainage layers. Infiltrating water, when encountering a low permeability clay layer, tends to be diverted downslope along the top of the clay layer. Water that does manage to.infiltrate through the clay layer tends not to infiltrate further if the underlying layer is composed of a coarse- 
ined material, such as sand or gravel. This engineered layer, referred to as a "capillary barrier," has been shown to be quite effective in greatly reducing infiltration through a waste disposal area.

Other engineered barriers that are incorporated into several of the current designs include concrete overpacks, sorbing backfill, and concrete vaults. Proposed engineered barriers not currently considered in any designs include engineered soil layers below the facility to provide adsorption of radionuclides and advanced engineered soil layers above the facility that incorporate a doublecapillary barrier. Each of the current designs for LLW disposal facilities that are being planned for States and compact regions has taken a different approach with respect to the use of these engineered barriers to ensure isolation of the waste from the environment.

\subsection{Purpose}

The purpose of this investigation is to identify and evaluate the use of engineered soils and other potential barriers or site modifications that may be used to enhance the near-field isolation characteristics of an LLW disposal facility. Previously used barriers (such as concrete overpacks, vaults, backfill, and engineered soil covers) are evaluated, as well as state-of-the-art barriers, including an engineered sorptive soil layer underlying the facility and an advanced design soil cover incorporating a double-capillary layer. Evaluations have been performed using performance assessment (PA) modeling techniques to calculate dose reduction factors, which quantify the relative improvements in long-term performance offered by these engineered barriers. The purpose of these analyses is to provide information in incorporating or excluding specific engineered barriers as part of new disposal facility designs.

\subsection{Organization of the Report}

This section provides a section-by-section description of the report organization. Chapter 2 provides a description of the general methodology, assumptions, input data, and implementation of the evaluation methodology, and verification and validation of the codes. Chapter 3 provides background information on the regulatory guidance related to LLW facility design and also provides a description of a reference facility, which serves as a baseline to compare the long-term performance of facility designs that incorporate engineered barriers. Chapter 4 identifies present practices of using engineered barriers to limit the release of radionuclides from LLW disposal facilities, including engineered soil covers, backfill, concrete overpacks, and vaults. The designs for the facilities proposed to be constructed in Texas, Illinois, California, Nebraska, Pennsylvania, and North Carolina are summarized.

Chapter 5 identifies additional state-of-the-art uses of engineered soils that may be reasonably expected to enhance the isolation characteristics of an LLW disposal facility. The barriers that are described are engineered soil layers placed beneath the facility and a sloped engineered soil cover with a double-capillary barrier design. Chapter 6 presents the results of the evaluations of the improvements in long-term performance offered by the previously described engineered barriers. Performance is expressed as a dose reduction factor relative to the performance of the reference design in representative arid and humid environments. Chapter 7 presents the logistics and incremental costs of incorporating these engineered barriers into a generic LLW disposal facility. A summary of the report and conclusions are provided in Chapter 8 , and references are provided in Chapter 9. 


\section{GENERAL STUDY METHODOLOGY AND ASSUMPTIONS}

This section describes the general methodology and assumptions used in the evaluation of the effectiveness of engineered barriers. A description of the computer codes used to implement the methodology and their verification are also provided.

\subsection{General Methodology}

A reference disposal facility design and various other enhanced facility designs that incorporate engineered barriers are defined. The reference design, which incorporates the bare minimum regulatory requirements, serves as a baseline to which the predicted long-term performance of the enhanced facility designs are compared. Design elements included in the enhanced facility designs are sloped engineered soil covers, backfill, concrete overpacks, vaults, engineered soil layers placed beneath the facility, and a sloped engineered soil cover with a double-capillary barrier design.

A performance measure has been calculated for the reference design and for each enhanced design that has been evaluated. The performance measure for each enhanced design was then divided by the performance measure for the reference design to form a relative performance measure for each design. This relative performance measure forms a basis for evaluating the long-term effectiveness of the various designs.

The primary regulatory criterion set forth in $10 \mathrm{CFR} 61$ for evaluating the long-term performance of an LLW disposal facility is the maximum annual dose equivalent received by a member of the public due to the presence of radioactive waste. It follows then that the most relevant performance measure for evaluating the effectiveness of proposed facility designs and site modifications would be some measure of the reduction in maximum dose offered by each alternative design relative to some reference design.

The specific performance measure that has been calculated for each alternative design was based on a dose reduction factor. This dose reduction factor was calculated from a summation of the timedependent fluxes (activity per unit time per cross-sectional area of the disposal facility) of each radionuclide leaving the bottom of the engineered structure. Calculation of these dose reduction factors was performed through the following steps:

- Identify a set of facility designs and site modifications that incorporate engineered barriers

- Collect physical, hydrologic, and chemical data required for the evaluation of the designs

- Perform flow simulations of the disposal facility configurations to obtain Darcy velocities and moisture contents within the waste disposal area

- Perform radionuclide screening to determine which key radionuclides are of concern and require detailed evaluations

- Perform source-term calculations to arrive at a tlux of each key radionuclide exiting the bottom of the disposal facility

- Decay and ingrow the fluxes of the key parent and daughter radionuclides leaving the disposal facility 
- Derive dose profiles for each parent and daughter radionuclide by multiplying the fluxes leaving the facility by dose conversion factors

- Sum the time-dependent radionuclide dose profiles over all key nuclides to derive a total dose profile

- Identify the maximum dose for each design option evaluated

- Divide the maximum dose for each design option by the maximum dose calculated from the reference design to derive a relative dose reduction factor.

The maximum dose calculated for each design option is based on ingestion of 2 liters per day of undiluted leachate, which is a grossly conservative assumption. However, the errors introduced by this assumption are equal for both the reference design and the enhanced designs, so that they cancel when the relative dose reduction factor is calculated. In this type of relative dose assessment, extraneous parameters that would otherwise be important in calculating quantitative doses, drop out of the equations.

In a quantitative performance assessment, site-specific parameters regarding the transport of radionuclides from the bottom of the disposal facility to a receptor-such as vadose zone thickness, groundwater velocities, porosity, permeability, head gradients, dispersion coefficients, and retardation coefficients-would need to be defined to provide a direct comparison to the regulation. The advantage of the relative dose assessment approach employed here is that the relative differences in the predicted doses from two facility designs can be accurately assessed at a generic site without the need for a large number of site-specific assumptions that may influence or perhaps dominate the results.

Details of the evaluation methodology are provided below.

\subsubsection{Infiltration of Water Through the Disposal Facility}

These analyses assume that the primary processes that control releases of contaminants from the disposal unit are as follows (Sullivan 1992): The llow of water through the disposal facility is a function of the amount of water available for movement through the facility and the ability of the material within the facility to transmit water. The ability of material within the facility to transmit water is a function of the permeability and moisture content of the materials. While the permeability of a particular material is a fixed value, the moisture content of the material can vary and will determine what portion of the overall permeability is availabie for flow.

To evaluate the impact of these processes on radionuclide transport from a waste zone, three designs were developed: a reference design, a single-capillary barrier design (Figure 2-1), and a double-capillary design. The single-capillary barrier design is similar to that being considered by a number of States in both arid and humid environments (e.g., Templeton et al. 1994: Oyen 1993; Anderson et al. 1993). The design also incorporates the work of Meyer (1993), Steenhuis et al. (1991), and Ross (1990), who argue in favor of an effective capillary barrier (i.e., gravel or coarse sand) beneath a low-permeability layer. The performance of the capillary barrier designs is measured as a dose reduction factor relative to the reference design.

The Variably Saturated 2-Dimensional Flow and Transport (VS2DT) code was used to calculate the moisture content and fluid velocity through the waste. Van Genuchten's (1980) model of 


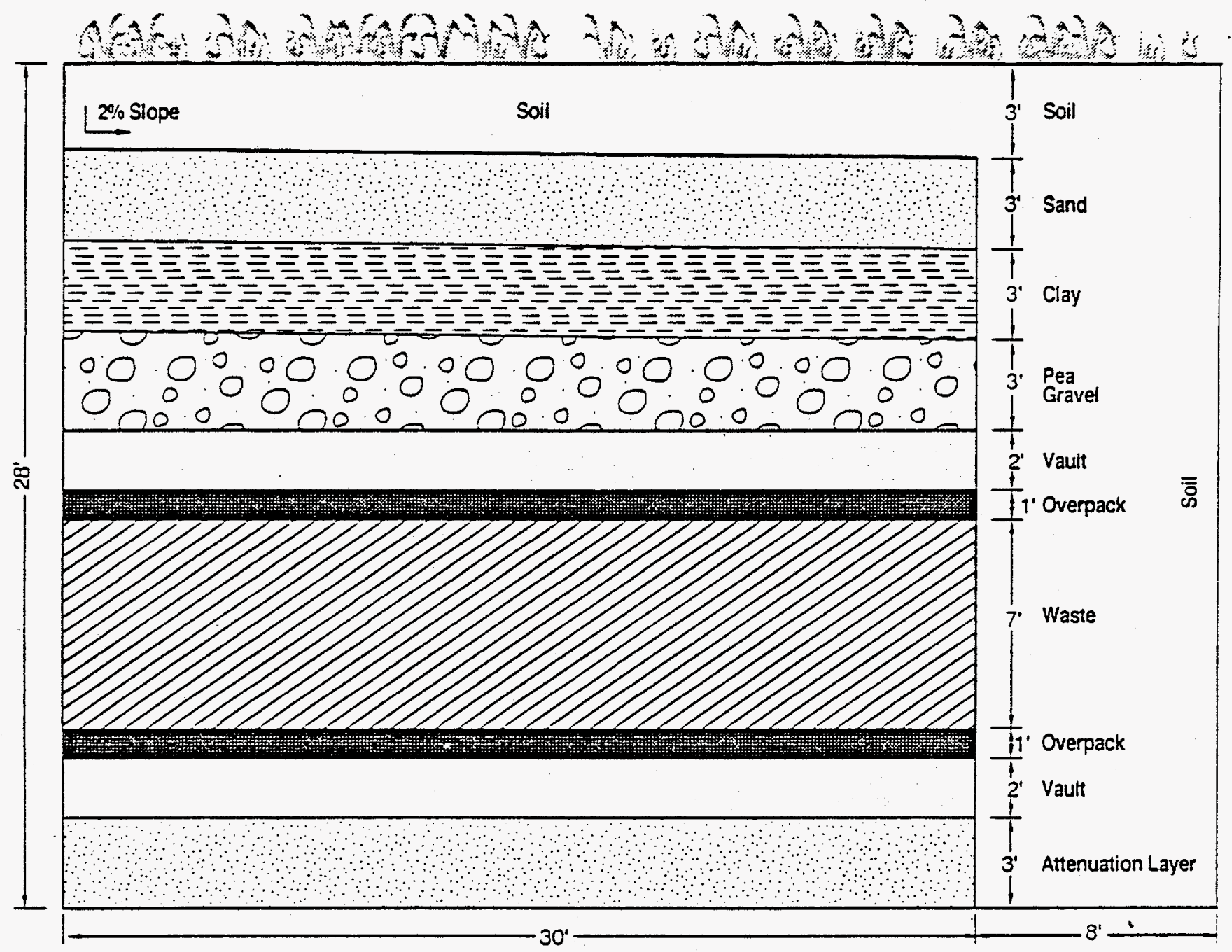

Drawing not to scale

Figure 2-1. Facility design, single-capillary barriç. 
moisture content and hydraulic conductivity as a function of pressure head was assumed to be valid and can be expressed as:

$\theta(\psi)=\theta_{R}+\left(\theta_{S}-\theta_{R}\right) /\left[1+(\alpha \psi)^{N}\right]^{M / 2}$

$\mathrm{K}(\psi)=\mathrm{K}\left\{1-(\alpha \psi)^{N-1}\left[1+(\alpha \psi)^{N}\right]^{-M}\right\}^{2} /\left[1+(\alpha \psi)^{N}\right]^{M / 2}$

where:

$\theta(\Psi)=$ moisture content as a function of pressure head

$\theta_{\mathrm{S}} \quad=$ saturated moisture content

$\theta_{R} \quad=$ residual moisture content

$K(\Psi)=$ hydraulic conductivity as a function of pressure head

$\mathrm{K}_{3} \quad$ = saturated hydraulic conductivity

$\boldsymbol{\Psi} \quad=$ pressure head

$\alpha \quad=$ independent parameter estimated in the laboratory from observed moisture retention data

$\mathrm{N} \quad=$ independent parameter estimated in the laboratory from observed moisture retention data

$\mathrm{M} \quad=1-1 / \mathrm{N}$.

The following additional assumptions were made:

- The system is at steady-state with respect to fluid flow.

- The infiltration rate is constant.

- Rare and extreme climactic events (such as flooding) were not considered.

- Simulation of flow starts after failure of the concrete vault and overpack.

- The failed concrete has the hydraulic properties of sand.

- Each layer within the model (Figure 2-1), including the waste, is homogeneous and isotropic with respect to unsaturated hydraulic properties.

Table 2-1 lists the unsaturated hydraulic properties of each material used in the model. All of the values are from soils reported by Carsel and Parrish (1988). 
Table 2-1. Unsaturated hydraulic properties of the flow-model layers.

\begin{tabular}{cccccc}
\hline Layer & $\mathrm{K}_{\mathrm{S}}(\mathrm{cm} / \mathrm{yr})$ & $\theta_{\mathrm{R}}$ & $\theta_{\mathrm{S}}$ & $\alpha(1 / \mathrm{cm})$ & $\mathrm{N}$ \\
\hline Soil & 38,719 & 0.065 & 0.41 & 0.075 & 1.89 \\
Sand & 260,172 & 0.045 & 0.43 & 0.145 & 2.68 \\
Clay & 1,752 & 0.068 & 0.38 & 0.008 & 1.09 \\
Pea gravel & 300,000 & 0.040 & 0.40 & 0.167 & 2.80 \\
\hline
\end{tabular}

One issue of concern in developing the model was how to simulate the hydraulic properties of the waste zone. It was assumed that the waste was essentially radioactively contaminated garbage, possibly consisting of disposable clothing, cleaning rags, metal pipes, or glassware and containing smaller percentages of combustible materials, resins, and sludges. The waste was also assumed to be compacted, since generators typically pay for disposal on a per-volume basis and compaction of LLW is routinely performed. It was further assumed that the containers (e.g., 55-gallon drums) had completely corroded and the waste zone could be treated as a homogeneous medium. There are few data in the literature on the hydraulic properties of such a waste zone. The waste scheduled for emplacement at the Waste Isolation Pilot Plant may have similar properties; Sandia National Laboratories/New Mexico (SNL/NM) (1992) defines an average intrinsic permeability of the waste as approximately $10^{-9}$ square centimeters $\left(\mathrm{cm}^{2}\right)$. This is approximately equivalent to a saturated hydraulic conductivity $\left(\mathrm{K}_{\mathrm{S}}\right)$ of about $3,094 \mathrm{~cm} / \mathrm{yr}$. SNLNM (1992) also defines a porosity of 0.19 , although this seems low. The authors of the U.S. Environmental Protection Agency (EPA) landfill evaluation code ("HELP") (Schroeder et al. 1984) suggest a default $\mathrm{K}_{\mathrm{S}}$ for waste of about $6,307 \mathrm{~cm} / \mathrm{yr}$ and a porosity of about 0.52 (probably more realistic than the 0.19 cited by SNL/NM). Unfortunately, neither reference provided (other than $\mathrm{K}_{\mathrm{S}}$ ) any of the unsaturated zone parameters required by VS2DT. To solve this problem without introducing additional uncertainty into the model, the waste zone was represented by a homogeneous sand with known unsaturated properties (Carsel and Parrish 1988).

The flow model allows fluid to move down-dip through the sloped layers of the engineered cap. off the edge of the cap, and down the side of the facility. Boundary conditions for the model were assumed as follows:

- Constant flux boundary across the top of the facility

- Constant tension boundary across the bottom of the facility

- Zero flux boundaries on both sides of the model.

The constant flux across the top was assumed to be $1.4 \mathrm{~cm} / \mathrm{yr}$ for an arid site and $34 \mathrm{~cm} / \mathrm{yr}$ for a humid site. These values are the average infiltration rates reported by the U.S. Department of Energy (DOE) (1993) for a number of their facilities. An infiltration rate of $1.4 \mathrm{~cm} / \mathrm{yr}$ is the average from the Hanford Site, Idaho National Engineering Laboratory, Nevada Test Site, and a generic site in the southwestern United States. An infiltration rate of $34 \mathrm{~cm} / \mathrm{yr}$ is the average from the Savannah River Site, Oak Ridge National Laboratory, and a generic site in the southeastern United States. 
The constant tension across the bottom of the model was specified as $\pm 2,500 \mathrm{~cm}$ for both arid and humid sites. This is approximately equal to the residual moisture content of sand. The initial moisture condition at the arid site was $\pm 200 \mathrm{~cm}$ of tension. At the humid site, the tension was initially $\pm 100 \mathrm{~cm}$; not only is this wetter condition more typical of a humid site, it was also necessary to achieve an adequate mass balance with the model. The model simulated 300 years of time to ensure adequate drainage of any initial moisture.

\subsubsection{Degradation of Engineered Barriers and Access of Water to the Waste Form}

Metallic barriers, such as drums and canisters, will degrade because of corrosion. Corrosion rates reported in the literature are generally higher than those anticipated in the disposal facility (in the absence of flooding), due to the limited availability of oxygen (which limits the rate of oxic corrosion) and to the low advective llow of water through the facility (which limits the dissolution rate of corrosion products). It is assumed in all cases that waste containers provide isolation for a period of 100 years, i.e., the duration of the institutional control period.

\subsubsection{Leaching of Contaminants from the Waste Form}

The term "leaching" in this report refers to the general process of release of contaminants from the waste into the leachant (infiltrating water). The three generally accepted mechanisms of radionuclide leaching are surface wash-off, diffusion, and dissolution (Sullivan 1992). Surface wash-off is expected to be the dominant mechanism of contaminant release from unstabilized waste forms. For robust waste forms involving immobilization of contaminants in the waste matrix (e.g., solidification), surface wash-off is not expected to be an important mechanism of contaminant release. Diffusion is expected to be the predominant mechanism of release from a porous waste form, such as cement. Dissolution is expected to be the primary mechanism of contaminant release from glass, ceramic, or other nonporous waste forms.

The regulation requires that the wastes must have "structural stability," and states that "a structurally stable waste form will generally maintain its physical dimensions and its form under the expected disposal conditions." The regulation, however, allows that "structural stability can be provided by the waste form itself, processing the waste to a stable form. or placing the waste in a disposable container or structure that provides stability after closure." Most of the waste in a typical disposal facility will thus be a mixture of stabilized and unstabilized waste forms. The use of containers to provide stability is a common practice, but stabilizing certain types of waste by cementation is also commonly performed. Radionuclides present in cemented waste forms will be released by diffusion rather than by surface wash-off. Since the ratio of cemented versus uncemented waste is undefined in a generic disposal tacility, it is conservatively assumed for modeling purposes that the dominant mode of release in all cases is surface wash-off.

\subsubsection{Transport of Contaminants to the Disposal Facility Boundary}

Contaminants are transported to a disposal facility boundary through the mechanisms of advection and dispersion. The disposal facility boundary is defined for modeling purposes as the bottom of the engineered structure. The concentration and rate of a contaminant leaving a disposal tacility are functions of the contaminant release rate from the waste form, the moisture content, the velocity of the fluid flowing through the facility, the dispersion coefficient in the facility, and surface reactions between the contaminant and the backfill (Sullivan 1992). 


\subsubsection{Adsorption of Radionuclides}

The effects of radionuclide adsorption on dose reduction are evaluated in designs that include sorbing backfill and designs that include a sorptive engineered soil beneath the facility. The adsorption coefficients $\left(\mathrm{K}_{\mathrm{g}}\right)$ used in these designs are provided in Table 2-2. All other designs assumed $K_{d}$ values of zero (no adsorption).

Table 2-2 Adsorption coefficients $\left(\mathrm{K}_{\mathrm{d}}\right)$ for the backfill and sorptive engineered soil layer.

\begin{tabular}{llc}
\hline & Element & Adsorption coefficient (mL/g) \\
\cline { 2 - 3 } Americium & $(\mathrm{Am})$ & $4,700^{\mathrm{a}}$ \\
Carbon & $(\mathrm{C})$ & $60^{\mathrm{a}}$ \\
Cesium & $(\mathrm{Cs})$ & $2,000^{\mathrm{a}}$ \\
Curium & $(\mathrm{Cm})$ & $3,162^{\mathrm{a}}$ \\
lodine & $(\mathrm{I})$ & $0.2^{\mathrm{a}}$ \\
Lead & $(\mathrm{Pb})$ & $1,830^{\mathrm{b}}$ \\
Neptunium & $(\mathrm{Np})$ & $5^{\mathrm{a}}$ \\
Nickel & $(\mathrm{Ni})$ & $650^{\mathrm{b}}$ \\
Niobium & $(\mathrm{Nb})$ & $350^{\mathrm{a}}$ \\
Plutonium & $(\mathrm{Pu})$ & $1,800^{\mathrm{a}}$ \\
Protoctinium & $(\mathrm{Pa})$ & $500^{\mathrm{b}}$ \\
Radium & $(\mathrm{Ra})$ & $220^{\mathrm{a}}$ \\
Technetium & $(\mathrm{Tc})$ & $20^{\mathrm{b}}$ \\
Thorium & $(\mathrm{Th})$ & $3,000^{\mathrm{a}}$ \\
Strontium & $(\mathrm{Sr})$ & $124^{\mathrm{b}}$ \\
Uranium & $(\mathrm{U})$ & $3,000^{\mathrm{a}}$ \\
Yttrium & $(\mathrm{Y})$ & $4,600^{\mathrm{b}}$ \\
Tritium & $(\mathrm{H})$ & $0.3^{\mathrm{a}}$ \\
Cobalt & $(\mathrm{Co})$ & $50^{\mathrm{a}}$ \\
Silver & $(\mathrm{Ag})$ & $100^{\mathrm{a}}$ \\
\hline
\end{tabular}

\subsection{Assumptions}

\subsubsection{Identification of Representative LLW Radionuclide Inventory}

The radionuclide concentrations that were used to evaluate the performance of engineered barriers were based on representative commercial LLW radionuclide data provided in the 1992 Integrated Data Base (IDB) (DOE 1992). Specifically, the average radionuclide concentrations of commercial LLW in units of curies/cubic meter $\left(\mathrm{Ci} / \mathrm{m}^{3}\right)$ are listed in Table A.6 of the IDB and are reproduced here in Table 2-3. 
Table 2-3. Average radionuclide concentrations in disposed commercial LLW.

\begin{tabular}{|c|c|c|c|}
\hline Radionuclide & $\begin{array}{l}\text { Concentration } \\
\left(\mathrm{Ci} / \mathrm{m}^{3}\right)\end{array}$ & Radionuclide & $\begin{array}{c}\text { Concentration } \\
\left(\mathrm{Ci} / \mathrm{m}^{3}\right)\end{array}$ \\
\hline $\mathrm{H}-3$ & $1.08 E+\infty 0$ & Te-123 & 5.71E-07 \\
\hline C. 14 & $5.08 \mathrm{E}-03$ & I-125 & $4.57 \mathrm{E}-04$ \\
\hline Al-26 & $2.98 \mathrm{E}-10$ & $1-129$ & $2.10 E-05$ \\
\hline Si-32 & 3.73E-11 & I-131 & $5.30 E-03$ \\
\hline P-32 & $9.29 E-04$ & Cs-134 & $8.66 \mathrm{E}-02$ \\
\hline S-35 & $2.08 E-03$ & Cs- 135 & $1.11 E-05$ \\
\hline $\mathrm{Cl}-36$ & $6.14 \mathrm{E}-06$ & Cs- 137 & $2.43 E-01$ \\
\hline$K-40$ & $1.77 \mathrm{E}-07$ & $\mathrm{Ba}-137 \mathrm{~m}$ & $2.30 E-01$ \\
\hline Cr. 51 & $7.14 \mathrm{E}-02$ & Ce-141 & $1.65 E-03$ \\
\hline $\mathrm{Mn}-54$ & $3.90 \mathrm{E}-01$ & Ce-144 & $1.46 \mathrm{E}-02$ \\
\hline $\mathrm{Fe}-55$ & $3.11 E+\infty 0$ & Pr-144 & $1.46 \mathrm{E}-02$ \\
\hline $\mathrm{Fe}-59$ & $5.08 \mathrm{E}-03$ & Nd-144 & $1.69 E-10$ \\
\hline $\mathrm{Co-58}$ & 2.05E-01 & Pm-147 & $1.32 \mathrm{E}-02$ \\
\hline $\operatorname{co}-60$ & $2.24 \mathrm{E}+00$ & Tb-157 & $1.01 \mathrm{E}-10$ \\
\hline $\mathrm{Ni}-59$ & $1.36 \mathrm{E}-03$ & Tb-158 & 3.77E-10 \\
\hline $\mathrm{Ni}-63$ & 2.69E-01 & Hf-175 & $1.43 E-03$ \\
\hline $\mathrm{Zn}-65$ & $1.17 \mathrm{E}-01$ & Hf-181 & $3.24 E-03$ \\
\hline $\mathrm{Kr}-85$ & 8.15E-04 & Re-187 & $1.77 \mathrm{E}-11$ \\
\hline Sr -89 & $6.02 \mathrm{E}-03$ & Po-209 & $1.28 \mathrm{E}-10$ \\
\hline $\operatorname{Sr}=90$ & $6.99 \mathrm{E}-02$ & $\mathrm{Ra}-226$ & $2.85 E-04$ \\
\hline Y-90 & $6.99 E-02$ & Th-229 & $1.31 E-10$ \\
\hline$Y-91$ & $8.86 E-03$ & Th-230 & $1.72 E-08$ \\
\hline$Z=-95$ & $1.04 \mathrm{E}-02$ & Th-232 & $8.17 E-03$ \\
\hline $\mathrm{Nb}-94$ & $1.66 \mathrm{E}-05$ & $\mathrm{~Pa}-231$ & $1.02 \mathrm{E}-10$ \\
\hline Nb-95 & $1.92 \mathrm{E}-02$ & $U-233$ & $2.31 E-07$ \\
\hline Mo.93 & $9.27 \mathrm{E}-12$ & U-234 & 5.37E-05 \\
\hline TC-99 & $1.95 E-04$ & U.235 & $2.54 \mathrm{E}-05$ \\
\hline Ru-103 & $5.90 \mathrm{E}-0.4$ & U.236 & $7.89 \mathrm{E}-07$ \\
\hline $\mathrm{Ag}-108 \mathrm{~m}$ & $5.53 E-06$ & U-238 & $6.99 \mathrm{E}-03$ \\
\hline $\mathrm{Ag}-110 \mathrm{~m}$ & $3.60 E-02$ & $\mathrm{~Np}-237$ & $1.67 \mathrm{E}-07$ \\
\hline $\mathrm{Cd}-113$ & $4.22 \mathrm{E}-12$ & $\mathrm{Pu}-239$ & $7.71 E-06$ \\
\hline Sb-124 & $2.62 \mathrm{E}-03$ & $\mathrm{Pu}-240$ & $1.39 \mathrm{E}-06$ \\
\hline Sb-125 & $1.90 \mathrm{E}-02$ & $\mathrm{Pu}-242$ & $4.65 \mathrm{E}-07$ \\
\hline
\end{tabular}

a. Source: DOE 1992. 
A radionuclide screening model proposed by Seitz and Kocher (1993) was used to eliminate insignificant radionuclides from detailed evaluations to improve efficiency. The details and results of the screening calculation are provided in Appendix A. Of the 66 radionuclides listed in Table 2-3, 31 were identified by the screening model as possible contributors to dose. These 31 radionuclides were used in all subsequent analyses (refer to Appendix A).

\subsubsection{Definition of a Reference Waste Volume}

A representative volume of waste disposed of in a generic LLW disposal facility was needed for this evaluation. A representative volume was developed based on the average volume of several proposed LLW disposal facilities. The proposed design-capacity volumes for six of the various proposed sites are summarized in Table 2-4. The mean design-capacity volume of these six sites is estimated as $7.1 \times 10^{6}$ cubic feet $\left(\mathrm{ft}^{3}\right)$.

Table 2-4. Volumes of waste to be disposed by State disposal site.

\begin{tabular}{cc}
\hline $\begin{array}{c}\text { Compact disposal } \\
\text { site }\end{array}$ & $\begin{array}{c}\text { Design capacity volume } \\
\left(10^{6} \mathrm{ft}^{3}\right)\end{array}$ \\
\hline California & 10 \\
Texas & 1.8 \\
Pennsylvania & 7.05 \\
North Carolina & 10 \\
Illinois & 9 \\
Nebraska & 5 \\
\hline Mean & 7.1 \\
\hline
\end{tabular}

\subsection{Implementation of Evaluation Methodology}

The evaluation methodology described in Section 2.1 was implemented using the VS2DT, Disposal Unit Source Term (DUST), DECAY, and DOSE numerical codes. The rationale for the selection of these codes, their description, and their verification and validation are provided below.

\subsubsection{Rationale for the Selection of Codes for Use in the Effectiveness Evaluations}

Selection of the individual codes used in evaluating the engineered barriers was based on the following criteria:

- NRC-approved codes should be used where possible.

- The codes should be readily available and preferably be in the public domain.

- The codes should be adequately documented.

- The codes should be capable of evaluating the periormance of disposal facilities and waste forms at both generic and specific sites. 
- The codes should be modular in structure.

In developing the performance assessment methodology for the NRC (Kozak et al. 1990), the SNLNM staff reviewed and recommended a group of individual codes that could be integrated into a complete PA methodology. The SNLNM selection process considered the following general criteria:

- The modeling approach should be well-established and accepted by the user community.

- The model should be documented and based on the appropriate fundamental principies of chemistry and physics.

- The model should allow for consideration of the spatial and temporal variability of the simulated process.

- The model should address system characteristics as a function of time, track the waste inventory, and handle decay chains, since some daughter products are of more concern than their progenitors.

- Wherever possible, generic models should be chosen.

- The model should be simple enough to be compatible with the available data, and, where simplifying assumptions are made, those assumptions should err on the side of conservatism. However, the model must be flexible enough to simulate a full range of site-specific and facility-specific conditions.

The DUST and VS2DT codes were recommended by SNLNM for use by the NRC using the above criteria. The DECAY and DOSE codes are short "utility" class routines developed by IT Corporation. DECAY performs decay and ingrowth calculations, and DOSE performs activity-todose conversions. Descriptions of these codes follow.

\subsubsection{Description of the VS2DT Code}

VS2DT was developed by the U.S. Geological Survey (USGS) (Healy 1990) to solve solute transport problems in variably saturated media. It is an extension of an earlier code (VS2D) developed by Lapalla et al. (1987) and uses finite difference (FD) methods to solve the advectiondispersion equation. It is quite versatile and can simulate thow and transport over one- or twodimensional vertical cross sections or axially symmetric three-dimensional cylinders. Intercell conductivities can be computed by the arithmetic or geometric mean. Soil-moisture characteristics can be approximated by the Brooks and Corey model, the van Genuchten model, the Haverkamp model, or by using tabular data. Solute transport options include first-order decay, linear and nonlinear adsorption, and ion exchange. The code is written in FORTRAN 77 and can be casily modified for specific applications.

\subsubsection{Description of the DUST Code}

- The Breach, Leach, and Transport (BLT) code was recommended by SNLNM for the NRC PA methodology for use in detailed applications (Kozak et al. 1990). Since that time, the developer of the BLT code has developed a more flexible code for use in the NRC methodology (Sullivan 1992). 
The recent DUST code (Sullivan 1992) was selected as the code to model release and transport of contaminants to the disposal facility boundary.

The DUST code improves upon existing source-term models by allowing more flexibility in modeling the processes in the disposal facility. The code is expected to be widely used in deriving the source-term for PAs. The code accounts for the most important processes (e.g., fluid flow, container degradation, waste form leaching, and radionuclide transport) and parameters influencing release. Leaching is modeled through three different release mechanisms: surface wash-off with or without partitioning between the waste form and solution, diffusion-controlled release, and uniform dissolution in which a fixed fraction of the inventory is released every year.

Two different options in DUST are available for calculating transport of contaminants through the facility: the Multi-Cell Mixing Cascade (MCMC) model and the one-dimensional Finite Difference (FD) model. The FD model is much more flexible and is capable of simulating more processes than the MCMC model. The FD model checks to ensure that radionuclide solubilities are not exceeded, whereas the MCMC does not. If higher leach rates are assumed for the waste form, the solubility limits of actinides may be exceeded without this check. The FD model also permits the water velocity through the waste to be defined as a function of time, whereas the MCMC model permits only a single constant velocity to be specified for any given simulation using the DUST code.

For the current study, the waste form is assumed to be unstabilized, so that surface wash-off is the dominant mechanism of radionuclide contaminant release. This mechanism assumes that contaminants are available for release as soon as water contacts the waste. This equilibrium is expressed as a desorption, or partition coefficient. The partition coefficient is the ratio of the mass of contaminant adsorbed on the solid per unit mass of the solid, divided by the concentration in solution at equilibrium. Any fraction of the radionuclide inventory can be assigned to a surface wash-off mechanism. For the current study, partitioning of radionuclides between the waste form and the solution was not simulated, and solubility constraints were not invoked. For barrier designs involving a sorptive backfill, partitioning of radionuclides between the backfill and solution during transport through the facility was simulated using the FD model.

\subsubsection{Description of the DECAY Program}

The DECAY code is a postprocessor FORTRAN program that performs decay-chain calculations. The program reads the radionuclide fluxes predicted by the DUST code and accounts for the decay and ingrowth of radionuclides as they migrate across the disposal unit boundary. Based on screening of radionuclides, only certain radionuclides were considered for more detailed evaluations.

The decay and ingrowth of radionuclides were performed within the DECAY code using the following Bateman decay equations for straight-chain radioactive decay (Benedict et al. 1981):

$$
N_{i}=N_{1}^{0} \lambda_{1} \lambda_{2} \ldots \lambda_{i-1} \sum_{j^{\prime}-^{\prime} 1}^{i} \frac{e^{-\lambda_{j} t}}{\prod_{\frac{k^{\prime}{ }^{\prime} 1}{k_{*}^{\prime} j}}^{i}\left(\lambda_{k}-\lambda_{j}^{\prime}\right)} \quad\left(i^{\prime}>1\right)
$$


and

$$
N_{1}=N_{1}^{0} e^{-\lambda_{1} t} \quad(i=1)
$$

where:

$$
\begin{aligned}
& N_{i}=\text { number of atoms of radionuclide } i \\
& N_{1}^{0}=\text { number of atoms of the progenitor radionuclide } \\
& \lambda_{i}=\text { decay constant for radionuclide } i \\
& t \quad=\text { time. }
\end{aligned}
$$

The concentrations and fluxes of the progenitors in terms of activity were converted into equivalent atom concentrations and fluxes of the progenitors before applying the Bateman equations. The calculated concentrations and fluxes of the parents and progeny in terms of atoms were then converted into units of activity concentrations and fluxes.

\subsubsection{Description of the DOSE Program}

In order to quantify the reduction in dose offered by each engineered barrier, the fluxes of each key radionuclide exiting the bottom of the engineered structure were multiplied by a dose conversion factor. The dose conversion factors were calculated by taking the reciprocal of the effluent radionuclide concentrations in water tabulated in the most recent revision of Table 2, Column 2, of Appendix B to 10 CFR Part 20 (Federal Register 1993). These dose conversion factors take into account both whole-body doses and doses to specific affected organs. The lower the permissible water concentration, the higher the dose conversion factor. The time dependent fluxes for each parent and daughter radionuclide are multiplied by the radionuclide-specific dose conversion factors to arrive at a dose-versus-time profile for each radionuclide. The individual time-dependent radionuclide dose profiles were summed to derive a total dose profile (total dose versus timetable). A search algorithm then identifies the maximum dose and the time of the maximum dose for a given disposal system design, as well as the contributions of each radionuclide chain to the total dose.

\subsection{Verification and Validation of Codes}

Verification and validation of software were considered essential processes in the development of the evaluation methodology. Verification is an independent assessment of numerical correctness of the software results. Validation is an independent assessment of the theoretical correctness of the software. The VS2DT and DUST codes are considered to be "industry standards," and verification/validation was performed outside of the current effort. The DECAY and DOSE programs were verified/validated by comparison to the results of an independently developed program that uses a different calculational methodology. The following describes the verification/validation that has been performed for the various codes.

\subsubsection{Veriflcation and Validation of VS2DT}

The flow through the disposal facility was modeled by using the VS2DT code. VS2DT is an FD 
code that can be used to model both saturated and unsaturated flow and transport (Healy 1990). Recent discussions with the SNL/NM staff developing the NRC PA methodology indicated that VS2DT is now recommended as an alternative model to the previously recommended VAM2D model (Kozak and Olague 1993). VS2DT is a nonproprietary computer code published by the USGS. The code is well-documented and versatile, and has been used to simulate variably saturated flow and solute transport under a variety of hydrogeologic conditions. A study has recently been completed to identify the "code of choice" for use by SNLNM to simulate vadose zone and contaminant transport for environmental restoration activities. As part of the study, SNLNM staff benchmarked VS2DT against VAM2D (Huyakorn et aL. 1989) and several other codes that are used for PA applications. The SNLNM staff found that both codes gave comparable results but that VS2DT was significantly faster (McCord and Goodrich 1993).

In addition, McCord and Goodrich (1993) verified VS2DT by comparing their results with two analytical solutions. The first verification problem represented two-dimensional unsaturated flow to a water table that was solved analytically by Philip (1989). The second verification problem simulated two-dimensional saturated solute transport and was solved analytically by Javandel et al. (1984) and named "TDAST." The differences in mass predicted by the VS2DT code and the analytical solution were less than $2 \%$ for each verification problem.

\subsubsection{Verification and Validation of DUST}

Verification and validation of the DUST code have been conducted through a number of studies. The container degradation models (general and local failure) and the waste form release models (diffusion, uniform release, and surface rinse with partitioning) were independently verified by comparing the predicted results of known analytical solutions. The FD and MCMC models were extensively tested by comparing the predicted results to known analytical solutions and through comparison of the results predicted by the two models on identical problems. In all cases, there was excellent agreement between the various results.

\subsubsection{Verification and Validation of DECAY}

The DECAY code performs radionuclide decay and in-growth calculations using the Bateman decay equations for straight-chain decay. The code was verified by comparing the predicted results with the resuits predicted by the RADECAY and Microshield codes.

\subsubsection{Verification and Validation of DOSE}

The DOSE code was verified by comparing the predicted results with the results obtained through hand calculations. 


\section{GENERIC SITE AND FACILITY DESCRIPTION}

This section summarizes the regulatory guidance on the use of engineered soils, barriers, and site modifications to provide isolation of LLW from the environment. A reference facility design is also provided that meets the minimum regulatory requirements. The performance of this design is used as a baseline to compare the relative improvements offered by engineered barriers not incorporated into the reference design.

\subsection{Regulatory Guidance on LLW Disposal Facility Design}

The fundamental guidance on the placement and design of an LLW disposal facility is provided in 10 CFR 61 (CFR 1990). Section 61.7(b)(2) states "A cornerstone of the system is stability-stability of the waste and the disposal site so that once emplaced and covered, the access of water to the waste can be minimized. Migration of radionuclides is thus minimized, long-term active maintenance can be avoided, and potential exposures to intruders reduced." The 10 CFR 61 regulation further requires that the long-term performance of an LLW disposal facility be controlled by a combination of natural barriers and site design features. The regulation provides minimum natural characteristics that a disposal site must have to be acceptable. For instance, sites within a 100 -year flood plain, coastal high-hazard area, or wetland, are specifically excluded from consideration $(\$ 61.50)$.

Provisions of 10 CFR 61 that relate to disposal site design include the following:

$\$ 61.51$ (a)(1) "Site design features must be directed toward long-term isolation and avoidance of the need for continuing active maintenance after site closure."

$\$ 61.51$ (a)(3) The disposal site must be designed to complement and improve, where appropriate, the ability of the disposal site's natural characteristics to assure (sic) that the performance objectives of Subpart C of this part will be met."

$\$ 61.51(a)(4)$ "Covers must be designed to minimize to the extent practicable water infiltration, to direct percolating or surface water away from the disposed waste, and to resist degradation by surface geologic processes and biotic activity."

$\$ 61.51(a)(5)$ "Surface features must direct surface water drainage away from disposal units at velocities and gradients which will not result in erosion that will require ongoing active maintenance in the future."

$\$ 61.51(a)(6)$ The disposal site must be designed to minimize to the extent practicable the contact of water with waste during storage, the contact of standing water with waste during disposal, and the contact of percolating or standing water with wastes after disposal."

$\$ 61.52(a)(2)$ "Wastes designated as Class $C$ pursuant to $\$ 61.55$, must be disposed of so that the top of the waste is a minimum of 5 meters below the top surface of the cover or must be disposed of with intruder barriers that are designed to protect against an inadvertent intrusion for at least 500 years."

$\$ 61.52(a)(5)$ "Void spaces between waste packages must be filled with earth or other material to reduce future subsidence within the fill." 
$\$ 61.52(a)(6)$ "Waste must be placed and covered in a manner that limits the radiation dose: rate at the surface of the cover to levels that at a minimum will permit the licensee to comply with all provisions of $\$ 20.1301$ and $\$ 20.1302$ of this chapter at the time the license is transferred pursuant to $\$ 61.30$ of this part."

Minimum requirements thus include the minimization of contact between the waste and infiltrating water through the use of design features that should be evaluated for a 500 -year timeframe without the need for active maintenance.

\subsection{Reference Facility Design}

A reference facility design was developed to provide a baseline for evaluating the additional isolation of LLW provided by the engineered barriers described in Chapters 4 and 5 . The reference facility design shown in Figure 3-1 is meant to provide the minimum degree of isolation and does not include any design enhancements. An excavated disposal cell is filled with waste drums, which are surrounded by a nonsorbing sand backfill. The disposal cell is then filled to the ground surface with native soil obtained from excavating the disposal cell. 


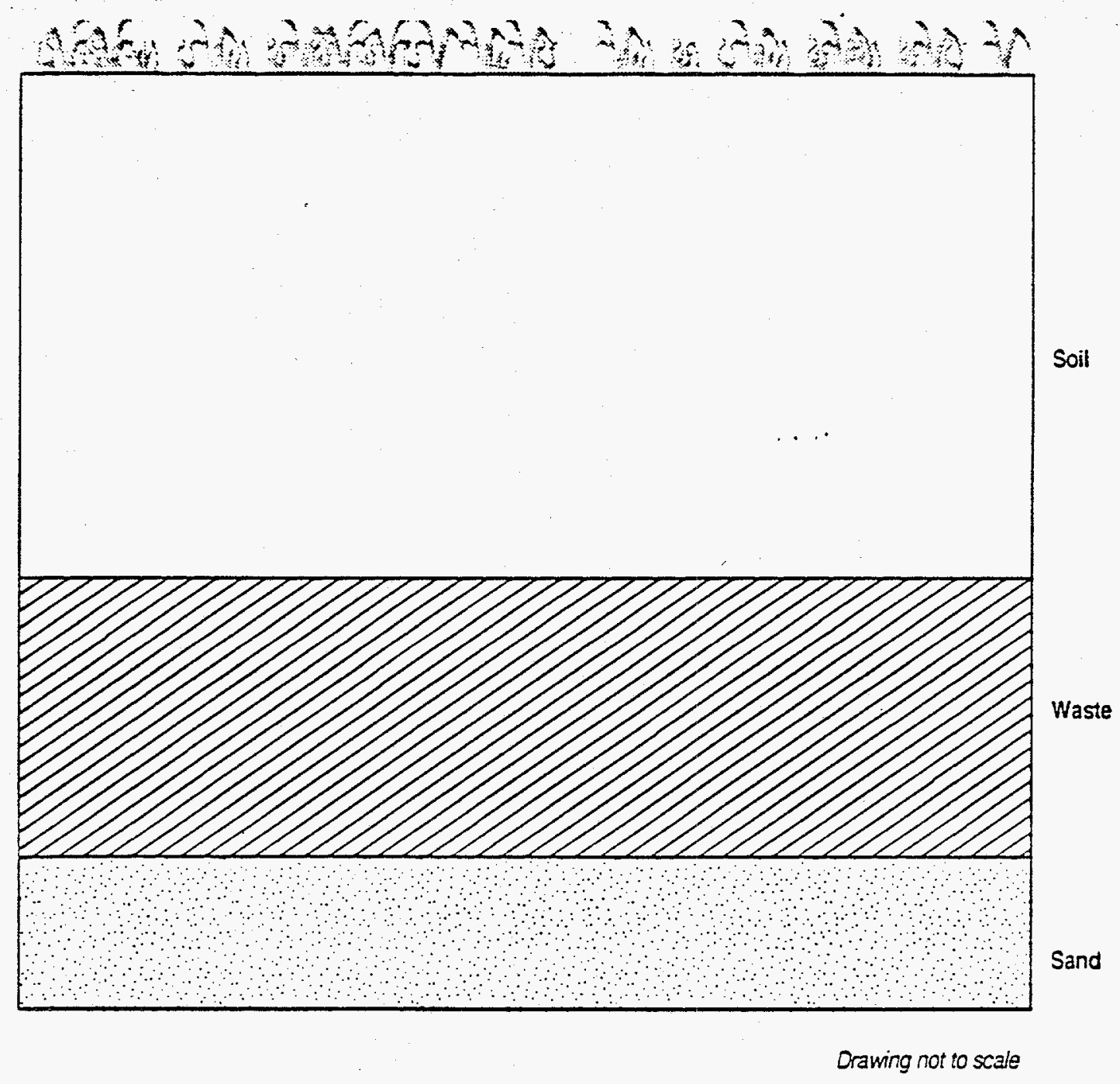

?

Figure 3-1. Reference design. 


\section{PRESENT PRACTICES OF USING ENGINEERED SOILS AND SITE MODIFICATIONS}

This section identifies engineered soils used in covers and backfills, concrete overpacks, and vault materials that are presently in use, identified, or suggested. These materials are chosen to enhance the isolation of LLW from the environment at existing or planned commercial LLW disposal facilities. The engineered barriers described here include those for previously or currently proposed facilities in Texas, Illinois, California, Nebraska, Pennsylvania, and North Carolina. Table $4-1$ presents a summary of the key design features for these planned LLW disposal facilities.

\subsection{Engineered Soil Cover/Cap System}

The function of an engineered soil cover over an LLW disposal cell is to minimize the infiltration of water into the waste, inhibit intrusion through the cap by plants and animals, and prevent the escape of radionuclides to the atmosphere. In the past, commercial LLW disposal facilities have used soil excavated during construction of a trench or cell for the cover. Although these soils did reduce infiltration into the trench, the covers were not engineered to minimize hydraulic conductivity or to provide a mechanism to collect and remove infiltrating moisture. Current designs are based on the concept of a multilayered cover of natural earthen materials, including topsoil, rip-rap, clay, sand, and gravel, and can include manmade layers such as flexible membrane liners, geosynthetic filter layers, and geosynthetic drainage layers.

Although the various cover designs being considered for LLW disposal facilities are different in many respects, the designs, with minor variations, are based on the concept of a multilayered cover consisting of both natural earthen materials and geosynthetic materials. The 10 CFR 61 regulations require that LLW disposal facility covers should minimize water infiltration, direct percolating water or surface water away from the disposed waste, and resist degradation by surface geologic processes and biotic activity. The EPA has recommended a cover design for hazardous waste disposal facilities. This design is state of the art for final covers and satisfies the requirements of 10 CFR 61 for limiting the water contact with waste and stability without active measures. Therefore, use of this basic design for hazardous waste disposal facilities, with site-specific modifications, is relevant to LLW disposal facilities. Each of the covers contains the three basic components of an EPA recommended cover-a composite low hydraulic conductivity layer, a drainage layer, and a vegetative/soil top layer (EPA 1991).

The function of the composite low hydraulic conductivity layer, composed of soil and a geomembrane, is to prevent moisture movement downward from the overlying drainage layer. The low hydraulic conductivity soil component placed over the waste should be at least $60 \mathrm{~cm}(24 \mathrm{in}$.) deep; free of detrimental rock, clods, and other soil debris; have an upper surface with a $3 \%$ maximum slope; and be below the maximum frost-line depth. The surface should be smooth so that no small-scale stress points are created for the geomembrane. The geomembrane placed on the smooth, even, low hydraulic conductivity layer should be at least $0.5 \mathrm{~mm}$ (20 mils) thick. The minimum slope surface should be $3 \%$ after any settlement of the soil layer or sub-base material has occurred (EPA 1991).

The drainage layer should be designed to minimize the time the infiltrated water is in contact with the bottom low hydraulic conductivity layer and, hence, to lessen the potential for the water to reach the waste. Water that filters through the top layer is intercepted and rapidly moved by gravity flow to an exit such as a toe drain. If the granular material in the drainage layer is sand, the minimum 
Table 4-1. Summary of low-level waste disposal facility design features-compact States.

\begin{tabular}{|c|c|c|c|c|c|c|}
\hline & Texias & Illinois & California & Nebraska & Pennsylvania & North Carolina \\
\hline $\begin{array}{l}\text { Volume of } \\
\text { waste }(\mathrm{cf})^{\mathrm{a}}\end{array}$ & $1.8+10^{6}$ & $8.6+10^{6} 109.4+10^{6}$ & $10^{7}$ & $5+10^{6}$ & $7.05+10^{6}$ & $10^{7}$ \\
\hline Concrete vault & No & Yes' & No & Yes & Yes & Yes \\
\hline $\begin{array}{l}\text { Concrele } \\
\text { overpack }\end{array}$ & Yes & Yes & No? & No & Yes & Yes \\
\hline $\begin{array}{l}\text { Type of } \\
\text { containers }\end{array}$ & $\begin{array}{l}\text { Drunis, cylinders, } \\
\text { rectangular boxes }\end{array}$ & $\begin{array}{l}\text { Drums, cylinders, } \\
\text { rectangular boxes }\end{array}$ & $\begin{array}{l}\text { Drums, cylinders, } \\
\text { rectangular boxes }\end{array}$ & $\begin{array}{l}\text { Drums, cylinders, } \\
\text { reclangular boxes }\end{array}$ & $\begin{array}{l}\text { Drums, cylinders, } \\
\text { rectangular boxes }\end{array}$ & $\begin{array}{l}\text { Drums, cylinders, } \\
\text { rectangular boxes }\end{array}$ \\
\hline Type of cover & $\begin{array}{l}\text { Mfultilayered } \\
\text { earthensynthelic }\end{array}$ & $\begin{array}{l}\text { Multilayered } \\
\text { earthen/synthetic }\end{array}$ & $\begin{array}{c}\text { Multilayered } \\
\text { earthen }\end{array}$ & $\begin{array}{c}\text { Multilayered } \\
\text { earthen/ reinforced } \\
\text { concrete }\end{array}$ & $\begin{array}{c}\text { Multilayered } \\
\text { earthen/synthetic? }\end{array}$ & $\begin{array}{c}\text { Multilayered } \\
\text { earthen/synthetic }\end{array}$ \\
\hline Type of backfill & $\begin{array}{l}\text { Cement-based } \\
\text { grout in } \\
\text { owerpacks; } \\
\text { crushed stone } \\
\text { between } \\
\text { overpacks }\end{array}$ & $\begin{array}{l}\text { Cement-based grout } \\
\text { in overpacts; } \\
\text { "cushioning } \\
\text { material" in vaults }\end{array}$ & $\begin{array}{l}\text { Native soil for } \\
\text { Class A; layers to } \\
\text { impede moisture } \\
\text { for Class B \& C }\end{array}$ & Compacted sand & $\begin{array}{l}\text { Cement based } \\
\text { grout in } \\
\text { overpacks; sand in } \\
\text { vaults }\end{array}$ & $\begin{array}{c}\text { Cement based grout in } \\
\text { overpacks; nothing in } \\
\text { vaults }\end{array}$ \\
\hline $\begin{array}{l}\text { Height of } \\
\text { waste stack }\end{array}$ & 2 overpacks & $20 \mathrm{ft}$ & $?$ & $\begin{array}{l}\text { Class } A-20 \mathrm{ft} \\
\text { Class } B / C-30 \mathrm{ft}\end{array}$ & $?$ & $20 \mathrm{ft}$ \\
\hline $\begin{array}{l}\text { Abowe/below } \\
\text { grade }\end{array}$ & Below & Above & Below & Above & $?$ & Above \\
\hline
\end{tabular}

a. $\mathrm{cf}=$ cubic fect. 
requirements are that it should be at least $30 \mathrm{~cm}$ (12 in.) thick with a hydraulic conductivity of $1 \times$ $10^{-2} \mathrm{~cm} / \mathrm{sec}$ or greater. Drainage pipes should not be placed in any manner that would damage the geomembranes. If geosynthetic materials are used in the drainage layer, the same physical and hydraulic requirements should be met, e.g., equivalency in hydraulic transmissivity, longevity, compatibility with geomembrane, compressibility, conformance to surrounding materials, and resistance to clogging (EPA 1991).

The upper layer of the two-component vegetative/soil top layer should be vegetation (or another surface treatment) that will allow runoff from major storms while inhibiting erosion. Vegetation over soil (part of which is topsoil) is the preferred system, although, in some areas, vegetation may be unsuitable. The surface slope should be the same as that of the underlying soils-at least $2 \%$ to promote deflection of infiltrating water, but no greater than $5 \%$ to minimize erosion. To support the vegetation, this top layer should be at least $60 \mathrm{~cm}(24 \mathrm{in}$.) deep and include at least $15 \mathrm{~cm}(6 \mathrm{in}$.) of topsoil. To help the plant roots develop, this layer should not be compacted. In some northern climates, this top layer may need to be more than the minimum $60 \mathrm{~cm}(24$ in.) to ensure that the bottom low hydraulic conductivity layer remains below the frost zone. The soil in the top layer should be $60 \mathrm{~cm}$ ( 24 in.) thick and capable of sustaining nonwoody plants; have an adequate waterholding capacity; and be sufficiently deep to allow for expected, long-term erosion losses. A mediumtextured soil, such as a loam, would lit these requirements. If the landfill site has sufficient topsoil, it should be stockpiled during excavation for later use (EPA 1991).

Currently, several different cover designs are being considered for proposed new LLW disposal facilities across the nation. Each of the proposed cap designs is based on the type of disposal facility being proposed (e.g., concrete vault, shallow trench, etc.). The following is a description of the proposed covers for the facilities to be constructed in Texas, Illinois, California, Nebraska, Pennsylvania, and North Carolina.

The Texas Low-Level Radioactive Waste Disposal Facility will use modular concrete canisters of waste, which will be placed in trenches. The final cover over the trenches will consist of $2 \mathrm{ft}$ of gravelly sand placed on the reinforced concrete caps of the canisters, followed by a 10 -in layer of asphaltic concrete, a geosynthetic clay liner, $5 \mathrm{ft}$ of native soil material, and a vegetative cover graded to a minimum of $2 \%$ to promote runoff (Radian Corporation 1993).

The Illinois LLW disposal facility design used concrete overpacks that would have been loaded with individual waste containers (drums or boxes) and sealed with cement-based grout and placed into concrete disposal modules (vaults). An engineered multilayered vault cover would have been constructed above each disposal unit. The vault cover consisted of, in ascending order, a 2.5- to 3.5-ft layer of compacted lower drain materiai (earthen), a 2-ft layer of low permeability soil, a high-density polyethylene (HDPE) liner, a 2-ft layer of upper drain material (earthen), and a vegetative layer consisting of a 16-in layer of subsoil overlain with an 8-in layer of topsoil (Chem-Nuclear Systems, Inc. 1991):

The proposed California LLW disposal facility will consist of shallow land burial trenches. The trenches will be $60 \mathrm{ft}$ deep for Class A wastes, and $42 \mathrm{ft}$ deep for Class B and C wastes. The upper $20 \mathrm{ft}$ of each trench will be filled with earthen materials as a cover (Oyen 1993) and will serve as a barrier for inadvertent intruders. For Class $A$ trenches, the $20 \mathrm{ft}$ of cover will be native soils. For the Class $B$ and $C$ trenches, the $20 \mathrm{ft}$ of cover will be multiple soil layers to impede moisture infiltration (Plummer and Morreale 1992). 
The Central Interstate Compact's Low Level Radioactive Waste Disposal Facility in Nebraska will consist of abovegrade, reinforced concrete disposal units. At the end of the facility operations, (the earlier of 30 years or receipt of $5,000,000 \mathrm{ft}^{3}$ of waste), closure operations will start. Abovegrade cell penetrations will be sealed with concrete, followed by a 6-in. thick topping slab poured over the cell roof paneis. The closure cap layers will then be installed in the following sequence (Deold and Coleman 1991):

- A synthetic liner placed over each cell extending partially down the side and end walls

- Sand placed around the cells to develop the configuration of the cap slopes

- A 3-ft-thick layer of clay placed over the entire area

- A 1.5-ft-thick reinforced concrete layer cast directly on the clay layer

- A 6-in-thick sand layer above the concrete layer with a geotextile filter on top

- A 5-ft-thick native soil layer placed directly on the geotextile over the.sand

- An erosion control layer placed over the entire cap. The upper portion of the caps will be covered with interlocking concrete grid blocks with open areas that permit vegetation growth. The cap sides will be covered with rock armor (rip-rap).

The Pennsylvania facility for disposal of LLW will consist of steel containers (drums) inside concrete overpacks (with cement based grout backfill), which will be placed into concrete vaults. This design consists of a multiple-layer engineered earthen cap, which provides several barriers. The concrete roof of the vault will be coated with a waterproof coating. Next, a layer of sand or permeable material will be placed and topped with clay, an HDPE liner, sand, and gravel, with topsoil and vegetation on top (Oyen 1993).

In North Carolina, the LLW disposal facility will use concrete overpacks that will be filled and then sealed with cement based grout to form waste packages. These waste packages will then be placed into concrete disposal modules (vaults). The vaults will be covered with a multiple-layered engineered earthen cover with the following four layers (Chem-Nuclear Systems, Inc. 1993), listed from top to bottom:

- A vegetative soil layer at least $2 \mathrm{ft}$ thick

- An upper earthen drainage layer at least $1 \mathrm{ft}$ thick

- A low-permeability layer will be composed of an HDPE liner, geosynthetic clay liner, and at least $1 \mathrm{ft}$ of low-permeability soil

- A lower earthen drainage layer.

\subsection{Backfill}

Backfill includes filler material placed in void spaces around waste containers within engineered structures, such as concrete overpacks and concrete vaults. Backfill material typically proposed for 
use today includes cohesionless material (e.g., sand and pea gravel) or something with significant compressive strength (e.g., concrete or cementitious grouts). Backfill provides three distinct benefits: fills voids to increase stability and minimize settlement, influences retrievability based on the type of backfill, and acts as a barrier by providing an adsorptive surface for retarding the transport of radionuclides.

Voids in near-surface LLW disposal units must be backfilled to reduce the potential for subsidence, water infiltration, and contaminant release from the disposal unit. In near-surface LLW disposal facilities, voids may progressively lead to settlement, subsidence, pooling of water on cover systems, and infiltration of water into disposal units. By ensuring that voids are backfilled, one major source of water infiltration into near-surface LLW disposal units can be largely eliminated (Danna 1991).

Backfilling has the potential of intluencing the ease with which emplaced packages may be retrieved. Removal of packages backfilled with sand would be much easier than removal of packages backfilled with a cementitious grout. The characteristics of the backfill could also influence the amount and chemistry of water contacting a waste and the nature and magnitude of any resultant leaching and release from the waste. The backfill may act as an added barrier, as in the case of concrete or grout, or can allow any percolating water to drain to the bottom of the disposal unit, as in the case of sand or gravel. The backfill can also have high sorptive capacity for certain radionuclides, which will enhance the isolation of the LLW from the environment by delaying the release of these radionuclides, thus providing additional time for decay. For example, zeolite sand and/or clay minerals (such as bentonite) may be used to substantially retard the migration of cationic radionuclides (such as cesium and strontium). Andisols, a soil taxonomic group consisting mostly of volcanic soils, may be used to substantially retard the migration of anionic radionuclides such as iodine and technetium (Schulz et al. 1992).

All of the proposed LLW disposal facilities mentioned above plan to use backfill either in the overpacks, in the vaults, in both overpacks and vaults, or in the case of California, around the waste containers in shallow trenches. In Texas, Illinois, Pennsylvania, and North Carolina, where modular concrete overpacks will be used, a cementitious grout will be placed in the overpacks around the drums. For Illinois, Nebraska, and Pennsylvania, where waste containers or overpacks are to be placed in vaults, either sand or crushed rock will be uşed as a backfill. In North Carolina, no backfill will be placed in the vaults. In California, native backfill material (for Class $A$ waste) or layered backfill to impede moisture movement (for Class $B$ and $C$ waste) will be placed around the waste containers in the shallow trenches.

NRC staff have studied the issues associated with backtills and have published some recommendations for filling voids between containers at LLW disposal facilities. To provide stability, the following three characteristics of the backfill were considered (NRC 1991):

- Conformability, so that when placed by the usual construction placement method (discharging or dumping over the waste drums and liners without any controlled spreading or compaction effort, making it unnecessary for workers to enter the disposal unit after it has been filled with LLW), the backlill material would freely move into and till the voids between the containers. Bridging of soil between containers and the formation of soil clumps that could result in large void openings remaining between the containers would thereby be avoided.

- Low Compressibility in the fill material despite the usual method of placement, which requires no formal densilication effort. 
- Gradation, which would ensure a sufficiently permeable fill material to allow any percolating water to drain to the bottom of the unit. Allowing drainage would help avoid prolonged contact of water with the waste, but the gradation would have an upper size limit that would prevent migration of fine-sized particles in the waste cover material from moving down into the intergranular pores of the fill materials placed between the containers.

Based on these characteristics, an analysis was conducted by the NRC to estimate the volume of voids that could reasonably be expected to exist between containers using two types of fill materials by (1) allowing for the placement of a cohesionless fill soil and (2) allowing for the placement of a cohesive soil. The study resulted in an estimation that the potential for settlement would be on the order of five times greater for a disposal trench where a cohesive soil is used as fill between waste containers than for a trench filled with a cohesionless soil (NRC 1991).

The cohesionless soils have desirable fill characteristics if they (1) allow the soil to better conform to the irregular openings between containers; (2) allow the soil to exhibit lower compressibility, even when initially placed without compactive effort; and (3) minimize the time that the LLW would be in contact with percolating water, if any, because of the fill soil's permeability (NRC 1991). Based on these desired characteristics, the NRC staff recommended that a cohesionless fill material be used in most cases and has provided guidance on fill material specifications and placement procedures.

\subsection{Modular Concrete Overpack}

Several States are considering modular concrete canister disposal (overpacks) for use in the facilities they intend to develop for LLW disposal. The modular concrete overpack disposal concept consists of placing one or several waste packages in individual concrete overpacks. Void spaces within the overpacks are then backfilled, usually with sand or grout, and the filled modular canisters are emplaced in the disposal unit. Modular concrete overpacks are presently being placed in nearsurface trenches, on concrete pads, and in concrete vaults.

Conventionally, modular concrete overpacks are fabricated offsite and transported to the disposal location for loading and placement. Because overall dimensions are typically on the order of a few feet, overpacks are transportable, though. and when filled. they are very heavy. Typically, steelreinforced concrete is used in the construction of the overpacks. Wall thicknesses might range from several inches to a foot. Overpacks could also be polymer-impregnated, which would increase their containment function (Danna 1991). The long-term performance of concrete is often controlled by the quality of its construction. Based on available documentation, it is likely that concrete can be formulated to have a service life in the range of 300 to 500 years. Such a service life will be obtained only if the concrete materials meet carcfully detined specifications, and good construction practices are followed (i.e., a good construction quality assurance/quality control (QAVQC) plan is established and implemented) (Clifton and Knab 1989).

Modular concrete overpacks are being considered for use at the Texas, Illinois. Pennsylvania, and North Carolina proposed LLW disposal facilities. In these cascs, grout will be used to backfill the overpacks.

\subsection{Concrete Vault}

Several States are considering the use of above or belowground vault disposal in their proposed facilities. In vault disposal, waste is placed in an engineered structure. The vault walls, roofs, and 
floors are typically constructed of reinforced concrete. As discussed in Section 4.3 above, concrete may be expected to have a service life of approximately 300 to 500 years if construction QAVC procedures are strictly adhered to. The vaults consist of individual cells whose boundaries are defined by their walls, floors, and roofs. Waste containers are placed into each cell, and void spaces between the individual containers may be backfilled. Where concrete or cementitious grout is used as a backfill material, the vaults effectively become solid blocks, and may be referred to as concrete monoliths. In these cases, the backfill becomes an added barrier. Sand or crushed rock may also be used as backfill (Danna 1991), which provides for easier retrievability of the waste packages.

Concrete vaults are being considered for use at the proposed Illinois, Nebraska, Pennsylvania, and North Carolina LLW disposal facilities. At the Nebraska facility, no concrete overpacks will be used. Instead, the waste cylinders will be placed directly into the vaults, which will then be backfilled with compacted sand. At the Illinois and Pennsylvania facilities, a cushioning material (sand) will be backfilled around the overpacks in the vaults. The North Carolina facility proposes no backfill in the vaults. 


\section{IDENTIFICATION OF ADDITIONAL POTENTIAL SOILS AND MODIFICATIONS}

This section identifies additional state-of-the-art uses of engineered soils that may be feasibly used and reasonably expected to enhance the isolation characteristics of an LLW disposal facility. The barriers that are described are engineered soil layers placed beneath the facility and a sloped engineered soil cover with a double-capillary barrier design.

\subsection{Engineered Soil Layers}

Three main purposes for placing engineered soil layers beneath LLW disposal facilities are to: (1) provide adequate mechanical support for the facility to prevent differential settling of the foundation, (2) provide a low-permeability barrier to limit the release of contaminated leachate, and (3) provide high radionuclide-specific sorptive capacity to retard the transport of radionuclides. Several factors must be taken into account when considering placing an engineered soil layer below an LLW disposal facility, specifically the engineering, hydrologic, and geochemical properties of the soils to be used. The following is a discussion of the implementability of placing engineered soils beneath an LLW disposal facility and the applicability of using high radionuclide-specific sorptive capacity soils to delay the migration of the radionuclides.

The foundation and liner soils underlying the facility must possess adequate bearing capacity and shear strength to support the expected loading, while providing an additional barrier between the waste materials and the environment by limiting seepage from the facility. Properly placed and compacted, the resulting soil mass has strength and support capabilities sufficient for most uses, as well as permeability or adsorption properties (Sandford et al. 1993). The soil liner and foundation systems must be designed and constructed for high strength, while maintaining a low permeability. Therefore, attention to quality control and quality assurance during construction is imperative. The main design considerations for stability of the liner/foundation system are strength and settlement. The main factors in achieving low permeability are soil type, gradation, plasticity, and compaction. The main factors in providing radionuclide retardation are the specific.adsorption coefficients for the radionuclides of interest.

Before facility design, representative samples of the liner and foundation material should be tested. The liner soil should be a fine-grained, poorly graded soil classified under the Unified Soil Classification System classification as an ML, $\mathrm{CL}$, or $\mathrm{CH}$. The soils should be tested for Atterberg limits to determine the plasticity. The strength of the liner and foundation soils can be determined using a triaxial compression test (American Society for Testing and Materials [ASTM] D2850-82). The direct shear test (ASTM D3080-72. D2573-72) or vane shear test may also be used. Laboratory compaction and permeability tests should be conducted to establish the relationships among moisture content, density, compactive effort, and permeability. Although both standard and modified Proctor tests (ASTM D698 and ASTM D1557-78, respectively) can be used, the standard Proctor test is preferred, because it results in a wetter optimum moisture content for a given soil. Fixed-wall, flexible-wall, and consolidation cell permeameters can be used to measure laboratory permeabilities and to establish the moisture content and compactive effort at which the minimum permeabilities may be achieved. Results of the strength, compaction, and permeability tests can be used to establish a range of acceptable values for parameters to be used in design (Goldman et al. 1988).

Settlement is not usually a problem for clay liner foundations (Goldman et al. 1988). However. since the foundation/liner would be exposed to the loads trom the disposal facility itself (concrete 
vaults, etc.), extensive testing should be performed to ensure that the selected materials are appropriate. Although the in situ native soils may possess the necessary properties of a foundation, some design engineers recommend excavating and recompacting the upper 1 to $2 \mathrm{ft}$ of foundation soil to control local settlement prior to liner installation (Goldman et al. 1988).

Differential settlement of the foundation can cause cracking of the clay liner due to localized structural stress. Therefore, the greater the liner's thickness and elasticity, the greater the tolerance range for differential settlement. A sufficiently thick liner can engage in self-healing if the subgrade settles nonuniformly (Goldman et al. 1988). The thickness of the liner for a specific site would be calculated based on the facility design, expected loading, and the properties of the soil to be used in construction of the liner.

Low-permeability engineered soils, when used as barriers, can virtually stop the flow of water or leachate out of a disposal unit. Plugging fractures in bedrock would allow the bedrock to act as a barrier beneath the facility instead of a conductive medium (Sandford et al. 1993). If necessary, underlying bedrock could be exposed and individual fractures treated at the surface with lowpermeability grout. A number of techniques have evolved to seal fractures and coat surfaces. Cement grouts with bentonite are usually used, but other grouts are available for special uses. However, in the case of the LLW disposal facilities, a "bathtub" effect could occur as the result of placing very low-permeability soils beneath the disposal units. This would allow the containment system (concrete vault, etc.) or the waste containers themselves to have prolonged contact with the leachate, causing increased corrosion rates and greater leaching of the waste. It is usually advisable to provide a layer overlying the waste that has a lower permeability than the engineered soils underlying the waste to avoid ponding of water within the waste storage area.

Engineered soil layers underlying the facility can be used to provide adsorption of radionuclides. The adsorption process will retard the velocities of specific radionuclides relative to the average velocity of groundwater through the soil layer. This additional engineered delay in radionuclide travel time from the disposal facility to an environmental receptor site will allow additional time for decay to occur, thus lowering the predicted dose in some cases. This can be particularly beneficial for fission products with relatively short half-lives (such as ${ }^{90} \mathrm{Sr}$ and ${ }^{137} \mathrm{Cs}$ ), where a few additional years of decay can significantly reduce the activities of these radionuclides before they are released from the facility. Minerals that provide high degrees of adsorption for specific radionuclides include clays, zeolites, and iron and manganese oxides. Clays and zeolites provide surfaces for the adsorption of cationic species $\left(\mathrm{Cs}^{+2}, \mathrm{Sr}^{+2}, \mathrm{UO}_{2}^{+2}, \mathrm{PuO}_{2}^{+2}\right.$, etc.), and iron and manganese oxides provide surfaces for the adsorption of anionic species $\left(\mathrm{I}^{-}, \mathrm{TCO}_{4}^{-}, \mathrm{UO}_{2}\left(\mathrm{CO}_{2}\right)_{2}{ }^{-2}\right.$, etc. $)$. Engineered soils that are either naturally or artificially enriched in these minerals can be tailored to provide adsorption for the specific radionuclides that are predicted to contribute to dose.

\subsection{Engineered Soil Cover with Double-Capillary Barrier}

It has been shown that a capillary barrier under a low-permeability layer will provide an effective barrier to partially-saturated fluid flow (e.g., Meyer 1993). The double-capillary barrier design is identical to the single-capillary barrier design, except there is an additional clay/gravel sequence (Figure 5-1). The additional layers are the same thickness as those in the single-layer design, although this doesn't have to be the case. The logic behind the double-layer design is that the second set of barriers will divert any tluid that gets past the first barrier and will probably be most affective under extreme infiltration events, such as very high rainfall, where the first barrier might become saturated. 


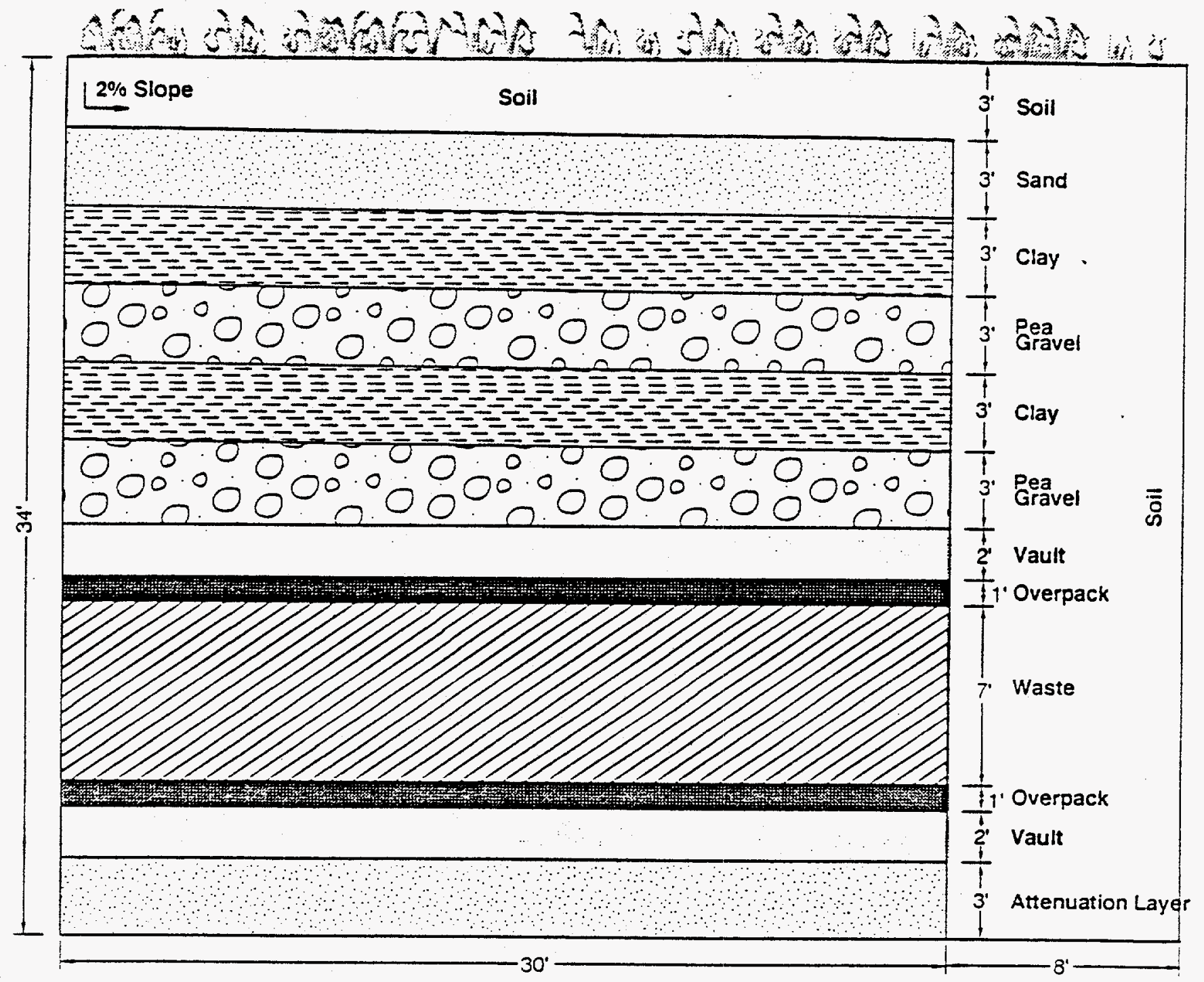

Drawing not to scale

Figure 5-1. Facility design, double-capillary barrier. 


\section{DEGREE OF ISOLATION ENHANCEMENT OF EACH IDENTIFIED ADDITION}

This chapter provides results of evaluations comparing the performance of the engineered barriers identified in Sections 4 and 5 with respect to the performance of the reference design in terms of dose reduction factors. For each facility design evaluated, a relative dose reduction factor is calculated as the ratio of the maximum dose for a modification to that of the maximum dose for the reference design. These relative performance measures thus provide an indicator of the amount of additional isolation that would be provided by the engineered modification(s) considered. Table 6-1 provides a matrix of engineered soils and other site modifications that were evaluated.

Table 6-1. Matrix of engineered soils and other site modifications evaluated.

\begin{tabular}{l|c}
\hline \multicolumn{1}{c|}{ Design } & Section \\
\hline Reference Design & 6.1 \\
Reference Design + Concrete Overpack & 6.1 \\
Reference Design + Concrete Vault & 6.1 \\
Reference Design + Concrete Vault + Overpack & 6.2 \\
Reference Design + Sorptive Backfill & 6.3 \\
Reference Design + Sorptive Backfill + Concrete Overpack & 6.4 \\
Reference Design + Sorptive Soil Layer Underlying Facility & 6.5 \\
Reference Design + Engineered Soil Cover with Single-Capillary Barrier & 6.6 \\
Reference Design + Engineered Soil Cover with Double-Capillary Barrier & 6.7 \\
Reference Design + Engineered Soil Cover + Sorptive Backfill + Underlying & \\
Sorptive Soil Layer + Concrete Vault + Concrete Overpacks & 6 \\
\hline
\end{tabular}

The performance of these configurations are evaluated at both the generic arid and generic humid disposal sites.

\subsection{Evaluation of the Effectiveness of Concrete Barriers}

For disposal configurations involving concrete engineered barriers (vaults and overpacks), releases of radionuclides are not assumed to occur for modeling purposes until the concrete barriers have failed. The NRC requires a 500-year service life of a concrete intruder barrier (Clifton and Knab 1989). An NRC-commissioned study on the service life of concrete performed by the National Institute of Standards and Technology concluded that "based on available knowledge, it seems likely that concrete can be formulated which should have service lives of 500 years in the expected environments" (Clifton and Knab 1989). 
Despite this optimistic view, the degradation of a concrete barrier in a disposal facility environment is a complex process that is difficult to accurately predict. Because of this uncertainty, the assumed time-to-failure is varied in this investigation from 100 to 1,500 years in seven increments. This analysis allows an assessment of the effects of containment failure time on dose reduction. A minimum longevity of 100 years (the reference case) is based on the requirement in $10 \mathrm{CFR} 61$ for 100 years of active institutional control, during which monitoring programs will be maintained to prevent any releases from the facility. A 300-year value is chosen to simulate the presence of concrete overpacks. A 500 -year value represents the expected failure time for a concrete vault, and an 800 year value represents an overpack and vault failing in series.

Calculated relative dose reduction factors at seven assumed failure times ranging from 100 to 1,500 years are shown in Table 6-2 and Figure 6-1. Results show that the relative doses decrease from a factor of 1.00 at 100 years (the reference case) to a factor of 0.84 , or a $16 \%$ reduction at 1,500 years. Also shown in Table $6-2$ is the percent contribution from the five key radionuclides that contribute $99 \%$ of the total dose. Only radionuclides that contribute greater that $1 \%$ of the total dose are shown. Doses caused by daughter products are summed with the parent so that the contribution from ${ }^{232} \mathrm{Th}$ shown in the table is actually the sum of doses from ${ }^{232} \mathrm{Th}+{ }^{228} \mathrm{Ra}$; and the contribution from ${ }^{238} \mathrm{U}$ is actually the sum of ${ }^{238} \mathrm{U}+{ }^{234} \mathrm{U}+{ }^{230} \mathrm{Th}+{ }^{226} \mathrm{Ra}+{ }^{210} \mathrm{~Pb}$. The extent that the daughter products contribute to the dose is dependent on the time between facility closure and the release of the parent from the disposal facility.

The gradual reduction in dose over the 100 to 1,500 year interval is due to decay of ${ }^{137} \mathrm{Cs}$ and

${ }^{90} \mathrm{Sr}$, which both have half-lives of approximately 30 years, and decay of ${ }^{226} \mathrm{Ra}$, which has a half-life of 1,600 years. The other two radionuclides that contribute to dose are ${ }^{232} \mathrm{Th}$ and ${ }^{238} \mathrm{U}$, which have half-lives of $1.4 \times 10^{10}$ and $4.5 \times 10^{9}$ years, respectively. These relative dose reduction factors and percent contribution from key radionuclides are identical for both the generic arid and humid sites, although the absolute dose at each containment failure time is 3.8 times higher at the humid site than the arid site.

These results suggest that a concrete failure time of 300 years will eliminate the dose contribution from ${ }^{137} \mathrm{Cs}$ and ${ }^{90} \mathrm{Sr}$, and that, assuming the IDB inventory, a 300 -year containment time will reduce the dose by $7 \%$ relative to failure at 100 years. Complete containment in excess of 800 years results in only a slight reduction in dose as the ${ }^{226} \mathrm{Ra}$ continues to decay.

\subsection{Evaluation of the Effectiveness of Sorptive Backfill}

Long-term performance of a disposal facility containing sorptive backfill at an arid and humid site was simulated. Sorption coefficients that were used for the sorbing backfill were discussed in Section 2.1.5. Results comparing the dose reduction factors relative to the reference design that contained a nonsorbing sand backfill are provided in Table 6-3.

Results show that the use of a sorbing backfill is predicted to decrease the dose by a factor of 3 to over 4 orders of magnitude, depending on the site. The appearance of ${ }^{129} \mathrm{I}$ as a key contributor is caused by the low degree of adsorption $\left(\mathrm{K}_{\mathrm{d}}=0.2 \mathrm{ml} / \mathrm{g}\right)$ relative to the other radionuclides. Conversely, the disappearance of ${ }^{238} \mathrm{U}$ as a key contributor is due to the high degree of adsorption $\left(\mathrm{K}_{\mathrm{d}}=3,000 \mathrm{~mL} / \mathrm{g}\right)$ relative to the other radionuclides. 
Table 6-2. Effects of concrete barrier failure time on relative dose reduction factor.

\begin{tabular}{|c|c|c|c|c|c|c|c|}
\hline \multirow{2}{*}{$\begin{array}{l}\text { Concrete } \\
\text { failure } \\
\text { time } \\
\text { (years) }\end{array}$} & \multirow[b]{2}{*}{$\begin{array}{c}\text { Design } \\
\text { simulated }\end{array}$} & \multirow{2}{*}{$\begin{array}{l}\text { Relative } \\
\text { dose } \\
\text { reduction } \\
\text { factor }\end{array}$} & \multicolumn{5}{|c|}{ Percent contribution from key radionuclides } \\
\hline & & & $\begin{array}{c}\text { Th-232 } \\
(\%)\end{array}$ & $\begin{array}{c}\mathrm{Ra}-226 \\
(\%)\end{array}$ & $\begin{array}{l}U-238 \\
(\%)\end{array}$ & $\begin{array}{c}\text { Cs-137 } \\
(\%)\end{array}$ & $\begin{array}{c}\mathrm{Sr}-90 \\
(\%)\end{array}$ \\
\hline 100 & Reference & 1.00 & 67.1 & 23.8 & 3.4 & 3.4 & 1.7 \\
\hline 300 & $\begin{array}{l}\text { Overpacks } \\
\text { with sand or } \\
\text { sorptive } \\
\text { backfill }\end{array}$ & 0.93 & 72.2 & 23.7 & 3.7 & - & - \\
\hline 400 & $\begin{array}{l}\text { Overpacks } \\
\text { with grout } \\
\text { backfill }\end{array}$ & 0.92 & $\begin{array}{c}73.0 \\
.\end{array}$ & 22.9 & 3.7 & - & - \\
\hline 500 & Vault & 0.91 & 73.7 & 22.2 & 3.7 & - & - \\
\hline 800 & $\begin{array}{l}\text { Overpacks + } \\
\text { Vault }\end{array}$ & 0.88 & 75.0 & 20.0 & 3.9 & - & - \\
\hline 1,000 & - & 0.89 & 77.1 & 18.7 & 3.9 & - & - \\
\hline 1,500 & - & 0.84 & 80.0 & 15.6 & 4.1 & - & - \\
\hline
\end{tabular}

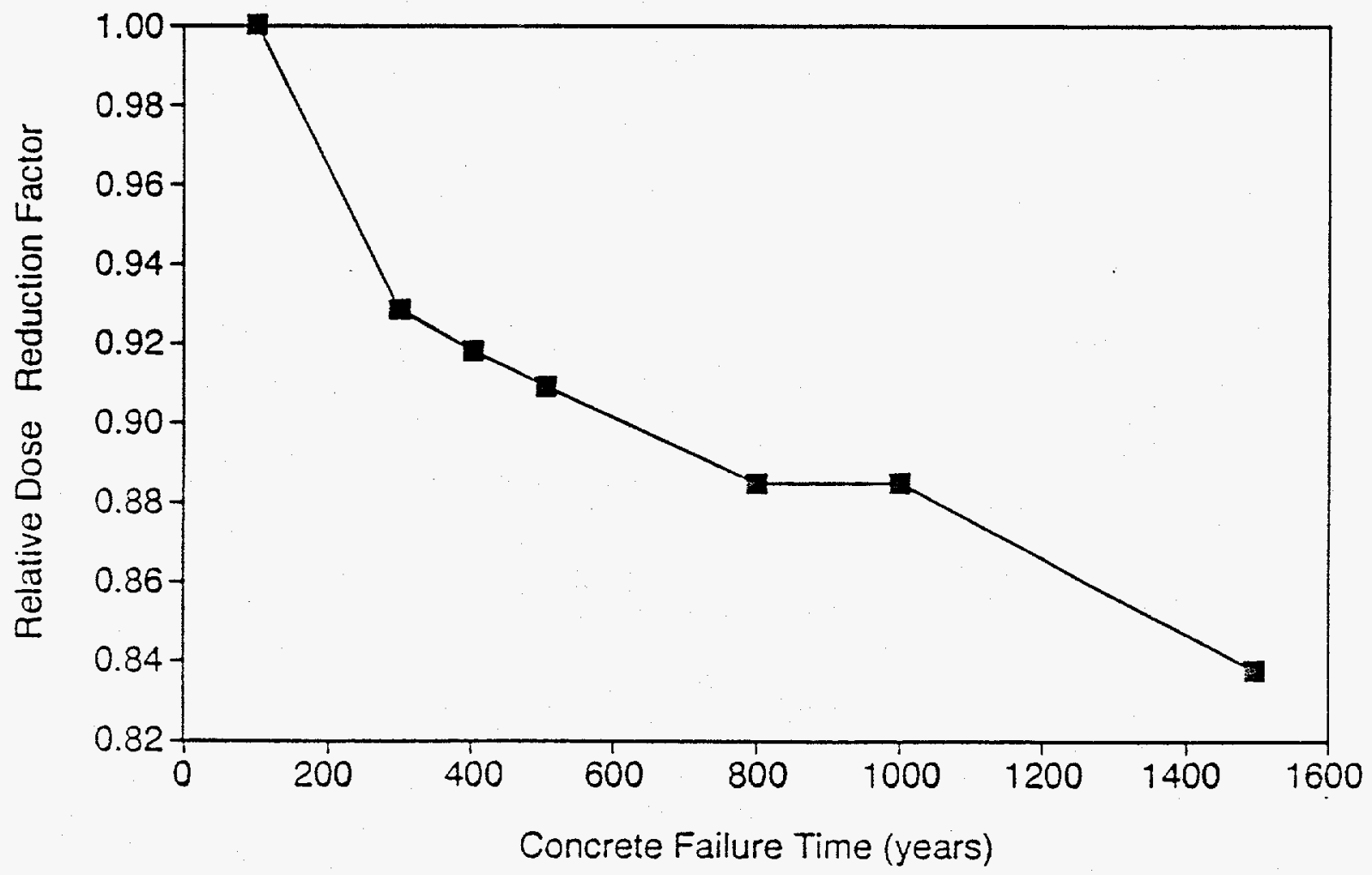

Figure 6-1. Relative dose reduction factor as a function of concrete failure time. 
Table 6-3. Effects of sorbing backfill on relative dose reduction factors.

\begin{tabular}{lcccccccc}
\hline & $\begin{array}{c}\text { Relative } \\
\text { dose }\end{array}$ & \multicolumn{5}{c}{ Percent contribution from key radionuclides } \\
\cline { 4 - 8 } Site & $\begin{array}{c}\text { reduction } \\
\text { factor }\end{array}$ & $\begin{array}{c}\text { Th-232 } \\
(\%)\end{array}$ & $\begin{array}{c}\text { Ra-226 } \\
(\%)\end{array}$ & $\begin{array}{c}\text { U-238 } \\
(\%)\end{array}$ & $\begin{array}{c}\text { Cs-137 } \\
(\%)\end{array}$ & $\begin{array}{c}\text { Sr-90 } \\
(\%)\end{array}$ & $\begin{array}{c}\text { I-129 } \\
(\%)\end{array}$ \\
\hline Reference design & 1.0 & 67.1 & 23.8 & 3.4 & 3.4 & 1.7 & - \\
$\begin{array}{l}\text { Arid site with } \\
\text { sorbing backfill }\end{array}$ & $5.6 \times 10^{-4}$ & 13.2 & 63.1 & - & - & 6.8 & 14.4 \\
$\begin{array}{l}\text { Humid site with } \\
\text { sorbing backfill }\end{array}$ & $1.54 \times 10^{-3}$ & 14.4 & 67.0 & - & 1.10 & 8.2 & 7.8 \\
\hline
\end{tabular}

\subsection{Evaluation of the Effectiveness of Designs Incorporating Sorptive Backfill and Concrete Overpacks}

Long-term performance of a disposal facility using a sorptive backfill and concrete overpacks at generic arid and humid sites was simulated. Sorption coefficients that were used for the engineered soil were the same as those used for sorbing backfill (Section 6.2) and are discussed in Section 2.1.5. The concrete overpacks were assumed to maintain complete containment for a period of 300 years. Results comparing the dose reduction factors relative to the reference design (nonsorbing sand backfill and no overpacks) are provided in Table 6-4.

Table 6-4. Relative performance of a disposal facility incorporating overpacks and sorbing backfill.

\begin{tabular}{lcccccccc}
\hline & \multirow{2}{*}{$\begin{array}{c}\text { Relative } \\
\text { dose }\end{array}$} & \multicolumn{5}{c}{ Percent contribution from key radionuclides } \\
\cline { 3 - 8 } \multicolumn{1}{c}{ Site } & $\begin{array}{c}\text { reduction } \\
\text { factor }\end{array}$ & $\begin{array}{c}\text { Th-232 } \\
(\%)\end{array}$ & $\begin{array}{c}\text { Ra-226 } \\
(\%)\end{array}$ & $\begin{array}{c}\text { U-238 } \\
(\%)\end{array}$ & $\begin{array}{c}\text { Cs-137 } \\
(\%)\end{array}$ & $\begin{array}{c}\text { Sr-90 } \\
(\%)\end{array}$ & $\begin{array}{c}\text { I-129 } \\
(\%)\end{array}$ \\
\hline Reference & 1.0 & 67.1 & 23.8 & 3.4 & 3.4 & 1.7 & - \\
Arid site & $6.92 \times 10^{-4}$ & 15.2 & 66.9 & - & - & - & 16.5 \\
Humid site & $2.59 \times 10^{-3}$ & 16.9 & 72.6 & - & - & - & 9.1 \\
\hline
\end{tabular}

These results show over a 4 order of magnitude reduction in dose at the arid site and over a 3 order of magnitude reduction in dose at the humid site relative to the reference design. The arid site has a $24 \%$ improvement, and the humid site has a $68 \%$ improvement over the case of sorbing backfill alone. This is because in both the backfill design and the backfill + overpack designs, the ${ }^{238} \mathrm{U}$ is strongly adsorbed and the ${ }^{129} \mathrm{I}$ is not: however, the overpack provides an additional 300 years of decay of ${ }^{137} \mathrm{Cs},{ }^{7} \mathrm{Sr}$, and ${ }^{226} \mathrm{Ra}$ before they are released. 


\subsection{Evaluation of the Effectiveness of a Sorptive Engineered Soil Beneath the Facility}

Long-term performance of a disposal facility using a sorptive engineered soil underlying the facility at generic arid and humid sites was simulated. Sorption coefficients that were used for the engineered soil were the same as those used for sorbing backfill (Section 6.2) and are discussed in Section 21.5. Results comparing the dose reduction factors relative to the reference design that did not use a sorbing layer under the facility are provided in Table 6-5.

Table 6-5. Relative performance of a disposal facility incorporating sorbing engineered soil beneath the facility.

\begin{tabular}{lcccccc}
\hline & Relative & \multicolumn{5}{c}{ Percent contribution from key radionuclides } \\
\cline { 3 - 7 } \multicolumn{1}{c}{$\begin{array}{c}\text { dose } \\
\text { Seduction }\end{array}$} & $\begin{array}{c}\text { Sh-232 } \\
\text { factor }\end{array}$ & $\begin{array}{c}\text { Ra-226 } \\
(\%)\end{array}$ & $(\%)$ & U-238 & Cs-137 & $\begin{array}{c}\text { Sr-90 } \\
(\%)\end{array}$ \\
\hline Reference & 1.0 & 67.1 & 23.8 & 3.4 & 3.4 & 1.7 \\
Arid site & 10.25 & 20.3 & - & 78.6 & - & - \\
Humid site & 0.79 & 92.9 & - & 6.1 & - & - \\
\hline
\end{tabular}

Results show only a $21 \%$ reduction in dose at the humid site and a factor of 10.25 increase in dose at the arid site relative to the reference design. These results are caused by the ingrowth of daughter products from the decay of ${ }^{232} \mathrm{Th}$ and ${ }^{238} \mathrm{U}$ during the hold-up time within the sorptive backfill. Peak doses are predicted to occur at 12,000 years at the humid site and 300,000 years at the arid site. With these long hold-up times, activity from the ingrowth of daughter products becomes significant and basically replaces the activity lost from the decay of the shorter half-live radionuclides such as ${ }^{137} \mathrm{Cs}$, ${ }^{90} \mathrm{Sr}$, and ${ }^{206 \mathrm{Ra}}$.

\subsection{Evaluation of the Effectiveness of Engineered Soil Cover with a Single-Capillary Barrier}

Long-term performance of a disposal facility using a sloped engineered soil cover at generic arid and humid sites was simulated using the methodology and assumptions provided in Section 2.1.1. Results in Table 6-6 show a 3 order of magnitude decrease in dose the arid site and a 2 order of magnitude decrease in dose at the humid site relative to the reference design. The percent contributions from key radionuclides are almost exactly the same as the reference design but the total doses are lowered because of the reduced infiltration rate through the facility.

\subsection{Evaluation of the Effectiveness of an Engineered Soil Cover with a Double-Capillary Barrier}

Long-term performance of a sloped engincered soil cover incorporating a double-capillary barrier was also simulated. Relative dose reduction factors for the double-capillary design were identical to those for the single-capillary design. A check of the fluid mass balance along a cross section through the middle of the waste zone at the end of the thow simulation indicates that the single-capillary 
Table 6-6. Relative performance of a disposal facility incorporating a sloped engineered soil cover overlying the facility.

\begin{tabular}{lcccccc}
\hline & Relative dose & \multicolumn{5}{c}{ Percent contribution from key radionuclides } \\
\cline { 5 - 7 } \multicolumn{1}{c}{ Site } & $\begin{array}{c}\text { reduction } \\
\text { factor }\end{array}$ & $\begin{array}{c}\text { Th-232 } \\
(\%)\end{array}$ & $\begin{array}{c}\text { Ra-226 } \\
(\%)\end{array}$ & $\begin{array}{c}\text { U-238 } \\
(\%)\end{array}$ & $\begin{array}{c}\text { Cs-137 } \\
(\%)\end{array}$ & $\begin{array}{c}\text { Sr-90 } \\
(\%)\end{array}$ \\
\hline Reference & 1.0 & 67.1 & 23.8 & 3.4 & 3.4 & 1.7 \\
Arid site & $1.3 \times 10^{-3}$ & 68.6 & 24.2 & 3.5 & 2.2 & 1.1 \\
Humid site & 0.02 & 67.2 & 23.9 & 3.4 & 3.4 & 1.7 \\
\hline
\end{tabular}

barrier cap design diverts approximately $99 \%$ of the applied flux at both the arid and humid sites. This is consistent with what was reported by Meyer (1993) for a sloped 90 -cm-thick clay underlain by a gravel-capillary barrier. The resuits were the same with the double-capillary barrier cap design.

These analyses were based on an assumption of steady-state hydrologic conditions; that is, the average precipitation and intiltration rates are constant over time. In reality, rainfall tends to be episodic. During intermittent periods of heavy rainfall, such as a 100 -year or 500 -year event, saturation of the overlying clay layer may occur. Under these conditions, the second clay layer may then become active in diverting water that has infiltrated past the first clay layer. The second layer may also become active if the first layer fails due to excessive drying and cracking, disruption by plant roots or burrowing animals, or erosion.

\subsection{Evaluation of the Performance of a Facility Using a Sloped Engineered Soil Cover, Sorptive Backfill, Underlying Sorptive Soil, Vault, and Overpacks}

The performance of a facility using a sloped engineered soil cover, sorptive backfill, underlying sorptive soil, vault, and overpacks was also evaluated at a generic arid and humid site. The combination of concrete vault and overpacks is assumed to provide complete containment for 800 years in this evaluation. Results shown in Table 6-7 indicate that a 4 order-of-magnitude decrease in dose relative to the reference design is predicted for both the humid and arid sites.

Table 6-7. Relative performance of a disposal facility incorporating a sloped engineered soil cover, sorptive backfill, underlying sorptive soil, vault, and overpacks.

\begin{tabular}{|c|c|c|c|c|c|c|c|}
\hline \multirow[b]{2}{*}{ Site } & \multirow{2}{*}{$\begin{array}{l}\text { Relative } \\
\text { dose } \\
\text { reduction } \\
\text { factor }\end{array}$} & \multicolumn{6}{|c|}{ Percent contribution trom key radionuclides } \\
\hline & & $\begin{array}{c}\text { Th-23 } \\
2 \\
(\%) \\
\end{array}$ & $\begin{array}{c}\mathrm{Ra}-22 \\
6 \\
(\%) \\
\end{array}$ & $\begin{array}{c}U-238 \\
(\%)\end{array}$ & $\begin{array}{c}\text { Cs-137 } \\
(\%) \\
\end{array}$ & $\begin{array}{c}\text { Sr-90 } \\
(\%)\end{array}$ & $\begin{array}{r}{[-129} \\
(\%) \\
\end{array}$ \\
\hline Reference & 1.0 & 67.1 & 23.8 & 3.4 & 3.4 & 1.7 & - \\
\hline Arid site & $7.03 \times 10^{-4}$ & 20.2 & 一 & 78.6 & 一 & - & - \\
\hline Humid site & $5.10 \times 10^{-4}$ & - & 99.9 & - & - & - & - \\
\hline
\end{tabular}




\section{LOGISTICS AND INCREASED COST OF EACH IDENTIFIED ADDITION}

This section presents and discusses the preparation, mechanics, and logistics associated with installation of engineered soil layers and an engineered soil cover with double-capillary barriers, as identified in Section 5. This section also presents the incremental costs associated with the engineered barriers detailed in Sections 4 and 5 .

\subsection{Logistics of Installing Engineered Soils}

Soil liner installation technologies are well developed. Implementation of these technologies is not complicated but requires strict attention to quality assurance/quality control practices. There are three main components in the installation of an engineered soil liner. The three general elements include preinstallation activities, clay liner installation, and postinstallation activities.

Before the liner is installed, a foundation must be prepared. Foundation construction is critical to the performance of an engineered liner system. To be effective, a liner system must remain intact. Differential settlement of the foundation can cause cracking in the liner material, thereby minimizing its effectiveness. The foundation of a clay-lined waste containment facility is the native soil substrate either unaltered or uncompacted. Operations during construction of the foundation start with stripping and excavating to remove all soft, organic, permeable, and otherwise undesirable materials. Top soils may be stockpiled for later use as cover material. Proof-rolling with heavy equipment-such as rubber-tired rollers or dozers-should be done to detect soft spots likely to cause settlement. 'Next, rock joints, clay fractures, depressions, and any areas where undesirable material has been removed must be filled. The fill material should be engineered backfill compacted to the required specifications or grouting material. At the end of foundation construction, the entire base can be seal-rolled (rolled smooth) to seal the soil and to ensure that any precipitation that may fall on the site before liner placement will run off and not puddle or pond on the foundation surface.

Clay liners are constructed by compacting clay soil in a series of lifts to ensure uniform compaction throughout the liner. For each liner lift, borrow material is emplaced into the facility with scraper-pans or trucks and uniformly distributed over the site with dozers or graders. Lift thickness is controlled during emplacement using measuring statis, shovel blades, or instrument surveys. Compaction of the clay liner is accomplished through standard compaction practices as used in other earthwork construction. There are several variables for compaction operations including lift thickness and number, equipment type and size, number of equipment passes (compactive effort), soil quality, and soil moisture content. Because these factors are interrelated, it is necessary to control all of these variables to achieve adequate compaction in the lield. Moisture content is one of the most critical factors to control when clay liners are compacted. This is because the moisture content requirements are different for compaction to achieve low permeability as opposed to compaction to achieve structural stability. Therefore, after laboratory tests are performed on the borrow material to determine the moisture-density relationships, it is usually prudent to construct a test pad using the same materials and equipment to be used in liner construction. Tests can then be performed on the test pad to ensure that the required properties (e.g., low permeability) are achievable.

Once the liner is constructed, it is rolled smooth to seal the surface. The completed liner is surveyed to ensure thickness, slope, and surface topography are as required in the design specifications. Seals around any objects penetrating the liner (e.g., antiseep collars around leak detection system pipes) should be checked for integrity. The liner can then be covered with plastic 
or a soil cover to prevent desiccation if any time will pass before the next liner system component is installed or before the liner is covered with waste. This is especially important for bentonite liners or for liners composed of native soils with a high capacity for swelling where desiccation cracking can occur very quickly.

Installation of an engineered soil cover with double-capillary barriers requires activities similar to those described above. Preparation, mechanics, and logistics for installation of this type of cover would be the same as for a single-capillary barrier, except that the time, equipment, and material requirements will increase, as will the cost.

\subsection{Incremental Costs of Engineered Barriers}

This section presents a comparison of capital and installation costs for the engineered soils and other site modifications detailed in Chapters 4 and 5. The incremental capital cost for each barrier was calculated based on the cost of improvements to the reference design. It is assumed that the cost of engineered soils (i.e., sorptive backfill or sorptive soil layers) and grout backfill will be negligible compared to the cost of native materials used for the same purpose in the construction of the reference facility, with the exception of clay and gravel. The quantity of materials (i.e., volume of clay for the multilayered cap or number of concrete overpacks) was determined based on a disposal facility capacity of 7.1 million $\mathrm{ft}^{3}$ of waste, as discussed in Section 2.2.2. It should be noted that these costs are the installed costs for the additional features of each site modification and should not be considered total life-cycle costs for the facility. It should also be noted that cost estimates for a generic facility will differ greatly from actual costs. Site-specific costs will be determined by factors such as distance from source of materials, actual disposal facility volume, dimensions of excavation, method of construction, etc.

The cost data used were obtained from 1992 studies of DOE and commercial, shallow-land disposal facilities. The data are order-of-magnitude estimates only and should only be used for rough comparison of competing alternatives. A risk model should be developed for the scenarios under investigation, and the cost of specific designs should be individually determined, with attendant risk factors. 
Table 7-1. Incremental capital and installation costs of engineered barriers relative to reference earth mounded shallow land disposal design.

\begin{tabular}{|c|c|c|c|}
\hline Disposal facility design & $\begin{array}{l}\text { Additional disposal facility } \\
\text { modifications }\end{array}$ & $\begin{array}{l}\text { Unit cost for additional } \\
\text { modifications }\end{array}$ & $\begin{array}{l}\text { Incremental capital cost for } \\
\text { generic LLW disposal facility }\end{array}$ \\
\hline $\begin{array}{l}\text { Reference design + engineered soil } \\
\text { cover }\end{array}$ & $\begin{array}{l}\text { Clay layer (3-feet thickness) } \\
\text { Gravel layer (3-fect thickness) }\end{array}$ & $\begin{array}{l}\text { \$21/cubic yard of clay } \\
\text { \$35/cubic yard of gravel/drain } \\
\text { material }\end{array}$ & $\$ 9.5$ million \\
\hline Reference design + sorptive backfill & Sorptive backfill & - & No additional cost \\
\hline Reference design + concrete vault & Concrete vault(s) & \$21/cubic foot of waste & \$147 million \\
\hline $\begin{array}{l}\text { Reference design }+ \text { concrete } \\
\text { overpacks (sand, sorptive, or grout } \\
\text { backfill around containers) }\end{array}$ & Concrete overpacks & $\$ 1,600 /$ overpack & \$196 million \\
\hline $\begin{array}{l}\text { Reference design + enginecred soil } \\
\text { cover, concrete vault, and concrete } \\
\text { overpacks }\end{array}$ & $\begin{array}{l}\text { Clay layer (3-feet thick) } \\
\text { Gravel layer (3-feet thick) } \\
\text { Concrete vault(s) and overpacks }\end{array}$ & $\begin{array}{l}\text { \$2i/cubic yard of clay } \\
\text { \$35/cubic yard of gravel/drain } \\
\text { material } \\
\$ 21 / \text { cubic foot of waste for vault } \\
\text { \$1,600/overpack }\end{array}$ & $\$ 353$ million \\
\hline $\begin{array}{l}\text { Reference design }+ \text { double capillary } \\
\text { barrier }\end{array}$ & $\begin{array}{l}\text { Two clay layers (3-feet thickness } \\
\text { for each) alternating with two } \\
\text { gravel layers ( } 3 \text {-feet thickness for } \\
\text { each) }\end{array}$ & $\begin{array}{l}\$ 21 / \text { cubic yard of clay } \\
\$ 35 / \text { cubic yard of gravel/drain } \\
\text { material }\end{array}$ & $\$ 19$ million \\
\hline
\end{tabular}

Source: Feizollahi and Shropshire, 1992 


\section{SUMMARY AND CONCLUSIONS}

This section summarizes the results of the simulations performed to evaluate the effects of various engineered barriers on the long-term performance of LIW disposal facilities. Table 8-1 summarizes the results of the design evaluations in terms of relative dose reduction factors (RDRF), which is the ratio of the predicted dose from the specific facility design divided by the predicted dose from the reference design.

Table 8-1. Relative dose reduction factors (RDRF) for LLW disposal facility designs at generic arid and humid sites.

\begin{tabular}{lcc}
\hline \multicolumn{1}{c}{ Design } & RDRF arid site & RDRF humid site \\
\hline Reference design (RD) & 1.00 & 1.00 \\
RD + overpack & 0.93 & 0.93 \\
RD + vault & 0.91 & 0.91 \\
RD + vault + overpack & 0.88 & 0.88 \\
RD + sorptive backfill & $5.60 \times 10^{-4}$ & $1.54 \times 10^{-3}$ \\
RD + sorptive backfill + overpack & $6.92 \times 10^{-4}$ & $2.59 \times 10^{-3}$ \\
RD + underlying sorptive soil & 10.25 & 0.79 \\
RD + engineered soil cover & $1.37 \times 10^{-3}$ & 0.02 \\
RD + overpack + vault + sorptive backfill + & $7.03 \times 10^{-4}$ & $5.01 \times 10^{-4}$ \\
underlying sorptive soil + engineered soil cover & & \\
\hline
\end{tabular}

Predicted doses are calculated by multiplying the peak annual lluxes of each radionuclide exiting the bottom of the disposal facility by dose conversion factors, which consider both whole-body and specific organ exposure. These absolute doses, which are based on ingestion of undiluted leachate, are overly conservative. However, the errors introduced by this overly conservative assumption are equal for both the reference design and the enhanced designs so that they cancel when the relative dose reduction factor is calculated. In this type of analysis, extraneous parameters that would otherwise be important in calculating quantitative doses drop out of the equations.

\subsection{Performance of the Reference Design}

A reference facility design was developed to use as a baseline for evaluating the additional isolation of LLW provided by the engineered barriers described in Chapters 4 and 5 . The reference facility design is meant to provide the minimum degree of isolation and does not include any design enhancements. An excavated disposal cell is filled with waste drums that are surrounded by a nonsorbing sand backfill. The disposal cell is then filled to the ground surface with native soil obtained from excavating the disposal cell. 
It is assumed that the reference design provides complete containment for the 100 -year active institutional control period, after which release may occur from the leaching and transport of radionuclides by infiltrating water. Doses from the referrence design are dominated by ${ }^{232} \mathrm{Th}(67.1 \%)$, ${ }^{226} \mathrm{Ra}(23.8 \%),{ }^{238} \mathrm{U}(3.4 \%),{ }^{137} \mathrm{Cs}(3.4 \%)$, and ${ }^{90} \mathrm{Sr}(1.7 \%)$. Absolute doses at the humid site are 3.8 times higher than at the arid site.

\subsection{Performance of Concrete Vaults and Overpacks}

The primary role of concrete vaults and overpacks is to provide complete containment for a few hundred years to allow the short-lived radionuclides $\left({ }^{90} \mathrm{Sr},{ }^{137} \mathrm{Cs}\right.$, and to a lesser extent $\left.{ }^{226} \mathrm{Ra}\right)$ to decay before being released. Results show that these types of barriers, when used alone or in combination, provide dose reductions in the range of a few percent to $16 \%$ relative to the reference design, and depend on the assumptions made regarding containment failure times. The maximum dose reduction of $16 \%$ assumed a 1,500-year containment time.

\subsection{Performance of Sorptive Backfill}

The purpose of a sorptive backfill is to provide reduced and delayed releases of radionuclides from the facility. The amount of delay and the decrease in the flux of each radionuclide exiting the facility is proportional to the adsorption coefficient, which varies for each element. Radionuclide sorption coefficients used in these analyses were provided in Table 2-2. Radionuclides that are released from waste that is emplaced at differing locations within the disposal facility will encounter differing path-lengths of sorbing backfill before leaving the facility. The differing path-lengths will yield differing travel times through the backfill, thus smoothing out the peak releases from the facility. Sorptive backfill is predicted to provide relative dose reduction factors of $5.60 \times 10^{-4}$ at the generic arid site and $1.54 \times 10^{-3}$ at the generic humid site.

An advantage of the use of sorptive backfill is that it can be assumed to remain effective for as long as necessary, whereas concrete barriers can only be assumed to remain effective for a finite period of time. The most effective naturally occurring minerals for the adsorption of radionuclides are clays, zeolites, and Fe- and Mn-oxides. These minerals are the chemically stable weathering products of igneous and metamorphic minerals that are unstable in the sedimentary environment. These weathering products should persist and remain effective tor an infinite length of time, unless they are physically disturbed by erosion or tectonic events.

\subsection{Performance of Sorptive Soil Layer Underlying Facility}

The main effect of a sorbing layer underlying the facility is to reduce the transport velocities of radionuclides that have high adsorption coefficients as they migrate through the underlying sorptive layer. The soil used in these evaluations had high sorptive properties for thorium and uranium. The predicted net effect of a long retention time for ${ }^{232} \mathrm{Th}$ and ${ }^{23} \mathrm{U}$ is to provide a roughly equivalent dose at the humid site and a higher dose at the arid site relative to the baseline, due to the ingrowth

of daughter products during the retention period. The ingrowth of these daughter products roughly compensates for the decay of the short-lived fission products, yielding doses that are in the same order of magnitude as the reference case, although the peak dose is delayed by thousands of years. 


\subsection{Performance of Engineered Soil Covers}

The main effect of a sloped engineered soil cover overlying the facility is to divert a certain percentage of the infiltrating water from entering the waste storage area. The results of flow modeling show that $99 \%$ of the infiltrating water is diverted by a properly designed cover. This diversion greatly reduces the velocity of infiltrating water through the disposal facility, thereby lowering the radionuclide flux exiting the facility by roughly 2 orders of magnitude. This corresponds to a relative dose reduction factor of $7.03 \times 10^{-4}$ at the generic arid site and $5.01 \times 10^{-4}$ at the generic humid site.

Evaluation of a design incorporating a double-capillary barrier was also performed. Results, assuming steady-state hydrologic conditions, provided relative dose reduction factors that were identical to the results from the single-capillary barrier design. There may still be an advantage to the double-capillary design, however, in maintaining performance under periods of heavy rainfall, such as a 100-year or 500-year event, when saturation of the overlying clay layer may occur. Under these conditions, the second clay layer may then become active in diverting water that has infiltrated past the first clay layer. The second layer may also become active if the first layer fails due to excessive drying and cracking, disruption by plant roots or burrowing animals, or erosion.

Once all of the waste has either decayed or has been leached from the facility, then the barriers no longer need to be effective. A potential disadvantage of the use of a sloped engineered soil cover is that it must be relied upon to be effective for an extensive period to meet the performance objectives, because the waste will be protected from rapid leaching. Sloped engineered soil covers composed of natural materials (clay, sand, gravel, etc.) are chemically stable in the natural environment but are subject to erosion. The use of boulders or rip-rap as an erosion cover has been proposed for stabilization of uranium mill tailings; these designs have life expectancies of about 1,000 years.

\subsection{Conclusions}

This section provides conclusions drawn from the results of the long-term performance evaluations. It should be kept in mind that the predicted effectiveness of disposal facility designs is dependent on several parameters including radionuclide inventory, infiltration rate, container longevity, and types of waste forms. Relative dose reduction factors will change to some extent if different assumptions are used.

Evaluation of the performance of designs incorporating concrete vaults and/or concrete overpacks shows relative dose reductions of 10 to 15 percent at most because they can be relied on to provide complete containment for only a few hundred to one or two thousand years. A sorbing layer of engineered soil underlying the facility provides only slight dose reduction at best and, under some conditions, can actually increase dose by allowing the buildup of daughter products from the decay of ${ }^{232} \mathrm{~T}_{\mathrm{i}}$ and ${ }^{238} \mathrm{U}$ before release.

A sloped, engineered soil cover, designed to divert infiltrating water, is expected to be quite effective in enhancing long-term performance by providing a 2 to 3 orders-of-magnitude decrease in dose. The only drawback to relying on this design element to meet the performance objectives is that it may need to remain effective in diverting infiltrating water for a significant period of time. This required longevity may be difficult to demonstrate if the cover is subject to erosion over the 
performance period; however, it is still very effective in enhancing the long-term performance of a disposal facility for up to a few thousand years.

Sorptive backfill is predicted to reduce doses by a factor of 3 to 4 orders of magnitude, which is a factor of 10 more effective than a sloped, engineered soil cover. The backfill can be designed to be chemically stable and, since the backfill surrounds the waste, it would be subject to erosion only if the waste itself eroded.

The most effective design would incorporate a combination of multiple redundant barriers to provide a high degree of confidence in the long-term performance of the disposal system. Designs that incorporate a sloped, engineered soil cover, which may be relied upon to remain effective for up to a few thousand years, and sorptive backfill, which will become active if and when the cover fails, will provide strong assurance of meeting the performance objectives. 


\section{REFERENCES}

Anderson, R. T., V. J. Barnhart, and M. T. Ryan, 1993, "Advanced Disposal Technologies for New Low-Level Waste Disposal Compact Sites," Proceedings of the Symposium on Waste Management, Tucson, Arizona.

Benedict, M., T. H. Pigford, and H. W. Levi, 1981, Nuclear Chemical Engineering, 2nd ed., New York: McGraw-Hill Book Company.

Buck, J. W., B. L. Hoopes, and D. R. Friedrichs, 1991, Multimedia Environmental Pollutant Assessment System Application Guide, Getting Started With MEPAS, PNL-7136, December 1991.

Carsel, R. F. and R. S. Parrish, 1988, "Developing Joint Probability Distributions of Soil Water Retention Characteristics," Water Resources Research 24, 5, pp. 755-769.

Chem-Nuclear Systems, Inc., 1993, Executive Summary of the License Applications for the North Carolina Low-Level Radioactive Waste Disposal Facility at the Wake/Chathan County Potentially Suitable Site, October 1993.

Chem-Nuclear Systems, Inc:, 1991, Illinois Low-Level Radioactive Waste Disposal Facility Application to Illinois Department of Nuclear Safety, May 15, 1991.

Clifton, J. R. and L. I. Knab, 1989, Service Life of Concrete, NUREG/CR-5466, November 1989.

Code of Federal Regulations (CFR), 10 CFR 61, "Licensing Requirements for Land Disposal of Radioactive Wastes," Office of the Federal Register, 1990.

Danna, J. G., R. D. Baird, N. Drehwing, E A. Jennrich, D. L. Siefken, and R. J. Starmer, 1991, Draft Identification of Potential Intermediate-Depth and Deep Geologic Disposal Concepts for Greater-ThanClass-C Low-Level Radioactive Waste, DOERLW-104a, June 1991.

Deold, J. H. and C. E Coleman, 1991, The Nebraska Facility, Engineered Barriers, Moisture Collection Systems and Environmental Monitoring," Thirteenth Annual U.S. DOE Low-Level Waste Management Conference, November 19-21, 1991, pp. 9-23.

DOE, see U.S. Department of Energy.

EPA, see U.S. Environmental Protection Agency.

Federal Register, 1993, 58 FR 67657, "Standards for Protection Against Radiation; Removal of Expired Materials," U.S. Nuclear Regulatory Commission, December 22, 1993, p. 67659.

Feizollahi, F. and D. Shropshire, 1992, Waste Management Facilities Cost Information Estimating Data, WTD-92-046, October 1992.

Goldman, L. J., L. I. Greenfield, A. S. Damie, G. L. Kingsbury, C. M. Northeim, and R. S. Truesdale, 1988, Design, Construction, and Evaluation of Clay Liners for Waste Management Facilities, EPAV 530-SW-86-007-F, November 1988. 
Healy, R. W., 1990, Simulation of Solute Transport in Variably Saturated Porous Media with Supplemental Information on Modifications to the U.S. Geological Survey's Computer Program VS2D, Water-Resources Investigations Report 90-4025, U.S. Geological Survey, Denver, Colorado.

Huyakorn, P. S., J. B. Kool, and J. B. Robertson, 1989, Documentation and User's Guide: VAM2D Variably Saturated Analysis Model in Two-Dimensions (Version 5.0 with Hysteresis and Decay Transport), NUREG/CR-5352, HCL/89-01, HydroGeoLogic Inc., Herndon, Virginia.

Javandel, I., C. Doughty, and C. Tsang, 1984, "Groundwater Transport: Handbook of Mathematical Modeis," Water Resources Monograph Series 10, American Geophysical Union, Washington, D.C.

Kozak, M. W., M. S. Y. Chu, and P. A. Mattingly, 1990, A Performance Assessment Methodology for Low-Level Waste Facilities, NUREG/CR-5532, SAND90-0375, Sandia National Laboratories, Albuquerque, New Mexico.

Kozak, M. W. and N. E Olague, 1993, "Updated Recommendations for Low-Level Waste Performance Assessment," Technology and Programs for Radioactive Waste Management and Environmental Restoration, Waste Management 93.

Lappala, E. G., R. W. Healy, and E. P. Weeks, 1987, Documentation of Computer Program VS2D to Solve the Equations of Fluid Flow in Variably Saturated Porous Media, Water-Resources Investigations Report 83-4099, U.S. Geological Survey, Denver, Colorado.

McCord, J. T. and M. T. Goodrich, 1993, Benchmark Testing and Independent Verification of the VS2DT Computer Code, SAND91-1526, draft, Sandia National Laboratories, Albuquerque, New Mexico.

Meyer, P. D., 1993, Application of an Infiltration Evaluation Methodology to a Hypothetical Low-Level Waste Disposal Facility, NUREG/CR-6114, PNL-8842, Vol. 1, Pacific Northwest Laboratory, Richland, Washington.

NRC, see U.S. Nuclear Regulatory Commission.

Oyen, L. C., 1993, "Low-Level Radioactive Waste Disposal and Nuclear Plant Storage Designs in the U.S.," Draft, Sargent and Lundy, Inc., Chicago, Illinois.

Philip, J. R., 1989, "Multidimensional Steady Infiltration to a Water Table," Water Resources Research, 25, 1, pp. 109-116.

Plummer, T. L. and B. J. Morreale, 1992, An Oveniew of Commercial Low-Level Radioactive Waste Disposal Technology, EGG-M-91476, 1992.

Radian Corporation, 1993, Texas Low-Level Radioactive Waste Disposal Facility, Project Summary, TX-RA-0728, December 1993.

Ross, B., 1990, "The Diversion Capacity of Capillary Barriers," Water Resources Research, 26, 10, pp. 2625-2629. 
Sandford, T. C., D. N. Humphrey, and F. A. DeMascio, 1993, "Use of Engineered Soils Beneath Low-Level Radioactive Waste Disposal Facilities," Fourteenth Annual U.S. Department of Energy Low-Level Radioactive Waste Management Conference Proceedings, CONF-921137-PROC. March 1993.

Sandia National Laboratories (SNL), 1992, Preliminary Performance Assessment for the Waste Isolation Pilot Plant, December 1992, Volume 3: Model Parameters, SAND92-0700/3, Sandia WIPP Project, Albuquerque, New Mexico.

Schroeder, P. R., A. C. Gibson, and M. D. Smolen, 1984, The Hydrologic Evaluation of Landfill Performance (HELP) Model, EPAV530-SW-84-010, Office of Solid Waste and Emergency Response, U. S. Environmental Protection Agency, Washington, D.C.

Schulz R. K., E O'Donnell, and E. C. Duckart, 1992, Anion Retention in Soil: Possible Application to Reduce Migration of Buried Technetium and Iodine: Development of a Field Test, NUREG/CR5974.

Seitz, R. R. and D. C. Kocher, 1993, "On Establishing Waste Concentration Limits for Low-Level Radioactive Waste Disposal," Proceedings of the Symposium on Waste Management, Tucson, Arizona.

Steenhuis, T. S., J. Y. Parlange, and K. J. S. Kung, 1991, "Comment on The Diversion Capacity of Capillary Barriers' by Benjamin Ross," Water Resources Research, 27, 8, pp. 2155-2156.

Sullivan, T. M., 1992, DUST Disposal Unit Source Term: Data Input Guide, NUREG/CR-6041, BNL-NUREG-52375, draft, Brookhaven National Laboratory, Upton, New York.

Templeton, K. J., S. J. Mitchell, P. M. Molton, and I. W. Leigh, 1994, Low-Level Radioactive Waste Disposal Technologies Used Outside the United States, EGG-LLW-11026 (94-1), National Low-Level Waste Management Program, Technical Bulletin, Idaho National Engineering Laboratory, Idaho Falls, Idaho.

U. S. Department of Energy (DOE), 1993, Mixed Low-Level Waste Systems Analysis Methodology and Applications Report, Vol. 2, DOE/LLW-194, draft, Office of Environmental Restoration and Waste Management, Washington, D.C.

U.S. Department of Energy (DOE), 1992, Integrated Data Base for 1992: U.S. Spent Fuel and Radioactive Waste Inventories, Projections, and Characteristics, DOE/RW-0006, Rev. 8, U.S. Department of Energy, Washington, D.C.

U.S. Environmental Protection Agency (EPA), 1991, Design and Construction of RCRA/CERCLA Final Covers, EPA625/4-91/025, May 1991.

U.S. Nuclear Regulatory Commission (NRC), 1991, Standard Review Plan for the Review of License Application for Low-Level Radioactive Waste Disposal Facility, NUREG-1200, Rev. 2, January 1991.

Van Genuchten, M. Th., 1980, "A closed-form equation for predicting the hydraulic conductivity of unsaturated soils," Soil Science Society of America Journal, 44, 5, pp. 892-898. 
Appendix A

Screening of Radionuclides 


\section{Screening of Radionuclides}

The radionuclide concentrations that were used in evaluating the performance of engineered barriers were based on representative commercial low-level waste (LLW) radionuclide data provided in the 1992 Integrated Data Base (IDB) (DOE 1992). Specifically, the average radionuclide concentrations of commercial LLW in units of curies per cubic meter $\left(\mathrm{Ci} / \mathrm{m}^{3}\right)$ are listed in the IDB are reproduced in Table 2-1.

Screening of the list of 70 radionuclides identified in the IDB was performed to eliminate insignificant radionuclides from the detailed evaluations to improve efficiency. The screening model proposed by Seitz and Kocher (1993) was used to establish trigger levels or conservative radionuclide concentrations. The trigger levels provide an indication of what constitutes a potentially significant concentration of a given radionuclide. If the concentration of a radionuclide in the waste form is below the trigger level, further calculations or data collection efforts are not required.

The starting point for the analysis was the following screening equation proposed by Seitz and Kocher(1993):

$$
T_{i}=\frac{D_{s d d} \theta R_{d}}{D_{\text {ing }} C_{r} e^{-\lambda_{i t}}}
$$

where

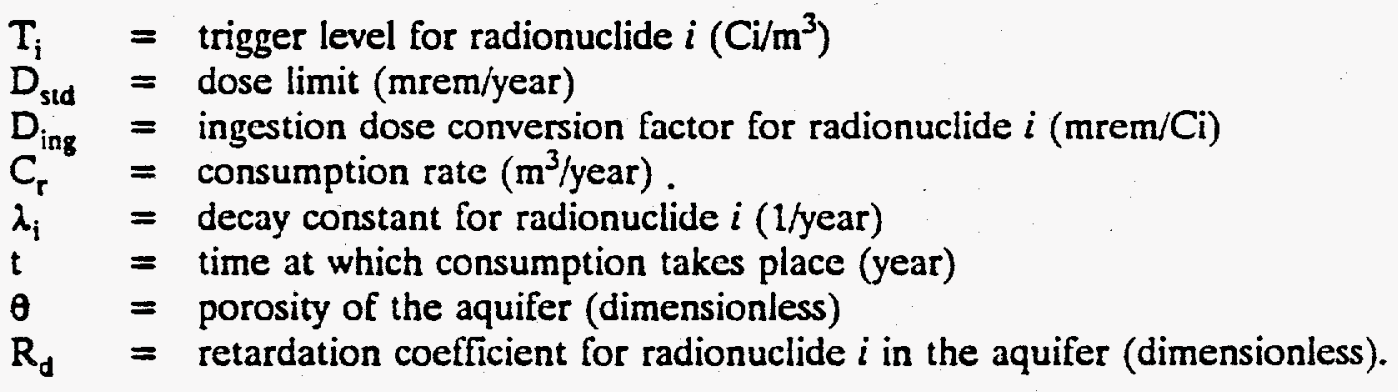

Equation (A-1) assumes that the entire waste inventory is deposited in the same volume of aquifer at time, $t$.

The factor $D_{\text {std }} /\left(D_{\text {ing }} C_{r}\right)$ is equivalent to a concentration limit of radionuclide $i$ in the groundwater. This factor or concentration limit will be denoted by the variable $C_{i}$ and has the units of $\left(\mathrm{Ci} / \mathrm{m}^{3}\right)$.

\section{A.1 RADIONUCLIDE SCREENING ASSUMPTIONS}

1. The time, $t$, was assumed to be 100 years, which corresponds to the end of the period of active institutional control. 
2. The retardation coefficient, $\mathbf{R}_{d}$, was conservatively assumed to be 1.0 , i.e. no credit was taken for retardation of radionuclides along potential flow paths.

3. The concentration limit of each radionuclide in the aquifer pore water, $C_{\mathrm{i}}$, was assumed to be equal to the permissible concentration of each radionuclide in effluent water as defined in Table 2 Column of Appendix B of 10 CFR Part 20, "Standards for Protection Against Radiation" (Fcderal Register 1993).

4. The porosity of the aquifer, $\theta$, was conservatively assumed to be 0.05 . This value is at the low end of values for sedimentary rock, such as sandstones, shales and limestones, and is within the porosity range of crystalline rocks (Domenico and Schwartz 1990). More realistic porosities for the aquifer are in the 0.30 to 0.50 range, which would have yielded trigger levels at least six times larger.

\section{A.2 CALCULATION OF TRIGGER LEVELS}

A spreadsheet application was developed to calculate the trigger level for each of the 70 radionuclides. The results of the screening analysis using the spreadsheet are summarized in Table A-1. The second column lists the radionuclide half-lives based on values reported in Appendix B of the 1992 IDB (DOE 1992). The third column lists the decay constant $\left(\lambda_{i}\right)$ for each nuclide that was calculated in the spreadsheet from the half-life as:

$$
\lambda_{i}=\ln \frac{2}{t_{1 / 2 i}}
$$

where

$\lambda_{\mathrm{i}} \quad=$ decay constant for radionuclide $i$ (1/year)

$t_{1 / 2 i}=$ half-life of radionuclide $i$ (year)

The fourth column lists the concentration of each radionuclide based on the values reported in the 1992 for commercial LLW. The fifth column in the table lists permissible concentrations as stipulated in 10 CFR Part 20 (NRC 1989). The sixth column lists the calculated trigger levels for each radionuclide as calculated using Equation (A-1) with the variable $C$ replacing the ratio $D_{\text {std }} /\left(D_{\text {ing }}\right.$ $C_{r}$ ) and using the values of the other variables listed earlier under assumptions. Entries in the sixth column designated by infinity indicate that the denominator is zero based on the very large values of the decay constant for the radionuclide. Since the denominator approaches zero. the trigger level approaches infinity, and the radionuclide is not of concern. The final column lists the ratio of the radionuclide concentration in the waste to that of the trigger level for each radionuclide. Thirty-one nuclides with a value greater than 1.0 were then considered in the evaluation of the performance of engineered barriers. 
Table A-1. Screening of radionuclides.

\begin{tabular}{|c|c|c|c|c|c|c|}
\hline Radionuclide & $\begin{array}{l}\text { Half-life } \\
\text { (yr) }\end{array}$ & $\begin{array}{c}\text { Decay } \\
\text { constant } \\
(1 / y r)\end{array}$ & $\begin{array}{l}\text { Concentration } \\
\left(\mathrm{Ci} / \mathrm{m}^{3}\right)^{\mathrm{a}}\end{array}$ & $\begin{array}{c}\text { Ingested } \\
\mathrm{H}_{2} \mathrm{O} \mathrm{DCG} \\
\left(\mathrm{Ci} / \mathrm{m}^{3}\right)\end{array}$ & $\begin{array}{l}\text { Trigger level } \\
\left(\mathrm{Ci} / \mathrm{m}^{3}\right)\end{array}$ & $\begin{array}{l}\text { Concentration } \\
\text { trigger level } \\
\text { (dimensionless) }\end{array}$ \\
\hline $\mathrm{H3}$ & $1.23 E+01$ & $5.64 \mathrm{E}-02$ & $1.08 \mathrm{E}+00$ & $1.00 \mathrm{E}-03$ & $1.41 E-02$ & $7.66 \mathrm{E}+01$ \\
\hline $\mathrm{Cl4}$ & $5.73 E+03$ & $1.21 \mathrm{E}-04$ & $5.08 \mathrm{E}-03$ & $3.00 \mathrm{E}-05$ & $1.52 \mathrm{E}-06$ & $3.35 E+03$ \\
\hline Al26 & $7.30 E+05$ & $9.50 \mathrm{E}-07$ & $2.98 \mathrm{E}-10$ & $6.00 \mathrm{E}-06$ & $3.00 \mathrm{E}-07$ & $9.93 E-04$ \\
\hline Si32 & $1.00 \mathrm{E}+02$ & $6.93 E-03$ & $3.73 E-11$ & $4.00 \mathrm{E}-05$ & $4.00 \mathrm{E}-06$ & $9.31 E-06$ \\
\hline P32 & $3.91 E-02$ & $1.77 \mathrm{E}+01$ & $9.29 E-04$ & $9.00 \mathrm{E}-06$ & Infinity & Infinity \\
\hline S35 & $240 E-01$ & $2.89 E+\infty 0$ & $2.08 E-03$ & $1.00 \mathrm{E}-04$ & Infinity & Infinity \\
\hline $\mathrm{Cl} 36$ & $3.01 \mathrm{E}+05$ & $2.30 \mathrm{E}-06$ & $6.14 E-06$ & $2.00 \mathrm{E}-05$ & $1.00 \mathrm{E}-06$ & $6.14 E+\infty 0$ \\
\hline $\mathrm{K}+0$ & $1.28 \mathrm{E}+09$ & $5.42 E-10$ & 1.77E-07 & $4.00 \mathrm{E}-06$ & $2.00 \mathrm{E}-07$ & 8.83E-01 \\
\hline Cr51 & $7.58 \mathrm{E}-02$ & $9.14 E+\infty$ & 7.14E-02 & $5.00 \mathrm{E}-04$ & Infinity & Infinity \\
\hline Mn54 & 8.55E-01 & $8.11 E-01$ & $3.90 \mathrm{E}-01$ & $3.00 \mathrm{E}-05$ & $2.48 E+29$ & $1.57 \mathrm{E}-30$ \\
\hline Fes5 & $273 E+\infty$ & $2.54 E-01$ & $3.11 E+\infty 0$ & $1.00 \mathrm{E}-04$ & $5.32 E+05$ & $5.85 E-06$ \\
\hline Fe59 & $1.22 \mathrm{E}-01$ & $5.70 \mathrm{E}+\infty 0$ & $5.08 \mathrm{E}-03$ & $1.00 \mathrm{E}-05$ & Infinity & Infinity \\
\hline $\operatorname{Co58}$ & $1.94 \mathrm{E}-01$ & $3.57 \mathrm{E}+\infty 0$ & 2.05E-01 & $2.00 \mathrm{E}-05$ & Infinity & Infinity \\
\hline $\operatorname{Co} 60$ & $5.27 E+\infty 0$ & $1.32 E-01$ & $2.24 E+\infty 0$ & $3.00 E-06$ & 7.71E-02 & $2.91 E+01$ \\
\hline Ni59 & $7.50 E+04$ & $9.24 \mathrm{E}-06$ & $1.36 E-03$ & $3.00 \mathrm{E}-04$ & $1.50 \mathrm{E}-05$ & $9.08 \mathrm{E}+01$ \\
\hline Ni63 & $1.00 E+02$ & $6.92 E-03$ & $2.69 \mathrm{E}-01$ & $1.00 \mathrm{E}-04$ & $9.99 \mathrm{E}-06$ & $2.69 E+04$ \\
\hline Zn65 & $6.68 \mathrm{E}-01$ & $1.04 E+00$ & 1.17E-01 & $5.00 \mathrm{E}-06$ & $2.76 E+38$ & $4.25 E-40$ \\
\hline Kr85 & $1.07 \mathrm{E}+01$ & $6.47 E-02$ & 8.15E-04 & $1.00 E-08$ & $3.22 \mathrm{E}-07$ & $2.54 E+03$ \\
\hline Sr89 & $1.38 \mathrm{E}-01$ & $5.01 E+\infty$ & $6.02 \mathrm{E}-03$ & $8.00 E-06$ & Infinity & Infinity \\
\hline $\mathrm{Sr} 90$ & $285 \mathrm{E}+01$ & $2.43 E-02$ & $6.99 \mathrm{E}-02$ & $5.00 \mathrm{E}-07$ & $2.85 E-07$ & $2.46 E+05$ \\
\hline Y90 & 7.31E-02 & $9.48 \mathrm{E}+00$ & $6.99 \mathrm{E}-02$ & $7.00 \mathrm{E}-06$ & Infinity & Infinity \\
\hline Y91 & $1.60 \mathrm{E}-01$ & $4.33 E+00$ & $8.86 E-03$ & $8.00 \mathrm{E}-06$ & Infinity & Infinity \\
\hline $\mathrm{Zr95}$ & 1.75E-01 & $3.95 E+00$ & $1.04 \mathrm{E}-02$ & $2.00 \mathrm{E}-05$ & Infinity & Infinity \\
\hline $\mathrm{Nb} 94$ & $2.03 E+04$ & 3.41E-05 & $1.66 \mathrm{E}-05$ & $1.00 \mathrm{E}-05$ & $5.02 E-07$ & $3.31 E+01$ \\
\hline $\mathrm{Nb95}$ & 9.57E-02 & $7.24 E+00$ & $1.92 \mathrm{E}-02$ & $3.00 \mathrm{E}-05$ & Infinity & Infinity \\
\hline Mo93 & $3.50 \mathrm{E}+03$ & $1.98 \mathrm{E}-04$ & $9.27 \mathrm{E}-12$ & $5.00 \mathrm{E}-05$ & 2.55E-06 & $3.64 \mathrm{E}-06$ \\
\hline $\operatorname{Tc} 99$ & $2.13 E+05$ & $3.25 \mathrm{E}-06$ & $1.95 \mathrm{E}-04$ & $6.00 \mathrm{E}-05$ & $3.00 \mathrm{E}-06$ & $6.49 E+01$ \\
\hline Rul03 & $1.07 \mathrm{E}-01$ & $6.45 E+00$ & $5.90 \mathrm{E}-04$ & $3.00 \mathrm{E}-05$ & Infinity & Infinity \\
\hline $\operatorname{Ag} 108^{m}$ & $1.30 \mathrm{E}+02$ & $5.33 E-03$ & $5.53 E-06$ & $9.00 E-06$ & $7.67 \mathrm{E}-07$ & $7.22 \mathrm{E}+00$ \\
\hline $\operatorname{Ag} 110^{m}$ & $6.84 \mathrm{E}-01$ & $1.01 E+\infty 0$ & $3.60 \mathrm{E}-02$ & $6.00 \mathrm{E}-06$ & $3.11 E+37$ & $1.16 \mathrm{E}-39$ \\
\hline $\operatorname{Cd} 113$ & $9.00 \mathrm{E}+15$ & $7.70 \mathrm{E}-17$ & 4.22E-12 & $4.00 \mathrm{E}-07$ & $2.00 \mathrm{E}-08$ & $2.11 E-04$ \\
\hline $\mathrm{Sb} 124$ & $1.65 \mathrm{E}-02$ & $4.21 \mathrm{E}+01$ & $2.62 \mathrm{E}-03$ & $7.00 \mathrm{E}-06$ & Infinity & Infinity \\
\hline $\mathrm{Sb} 125$ & $2.73 E+\infty 0$ & $2.54 \mathrm{E}-01$ & $1.90 \mathrm{E}-02$ & $3.00 \mathrm{E}-05$ & $1.60 E+05$ & 1.19E-07 \\
\hline Te123 & $1.30 \mathrm{E}+13$ & 5.33E-14 & 5.71E-07 & $2.00 \mathrm{E}-05$ & $1.00 \mathrm{E}-06$ & 5.71E-01 \\
\hline 1125 & $1.65 \mathrm{E}-02$ & $4.21 \mathrm{E}+01$ & $4.57 \mathrm{E}-04$ & $2.00 \mathrm{E}-06$ & Infinity & Infinity \\
\hline
\end{tabular}


Table A-1. (continued).

\begin{tabular}{|c|c|c|c|c|c|c|}
\hline Radionuclide & $\begin{array}{l}\text { Half-life } \\
\qquad(y r)\end{array}$ & $\begin{array}{c}\text { Decay } \\
\text { constant } \\
(1 / y r)\end{array}$ & $\begin{array}{c}\text { Concentration } \\
\left(\mathrm{Ci} / \mathrm{m}^{3}\right)^{\mathbf{a}}\end{array}$ & $\begin{array}{c}\text { Ingested } \\
\mathrm{H}_{2} \mathrm{O} \mathrm{DCG} \\
\left(\mathrm{Ci} / \mathrm{m}^{3}\right)\end{array}$ & $\begin{array}{l}\text { Trigger level } \\
\left(\mathrm{Ci} / \mathrm{m}^{3}\right)\end{array}$ & $\begin{array}{l}\text { Concentration/ } \\
\text { trigger level } \\
\text { (dimensionless) }\end{array}$ \\
\hline $\mathrm{H} 3$ & $1.23 E+01$ & $5.64 \mathrm{E}-02$ & $1.08 \mathrm{E}+\infty 0$ & $1.00 \mathrm{E}-03$ & $1.41 \mathrm{E}-02$ & $7.66 \mathrm{E}+01$ \\
\hline I129 & $1.57 \mathrm{E}+07$ & 4.41E-08 & $2.10 \mathrm{E}-05$ & $2.00 \mathrm{E}-07$ & $1.00 \mathrm{E}-08$ & $2.10 E+03$ \\
\hline 【131 & $220 \mathrm{E}-02$ & $3.15 E+01$ & 5.30E-03 & $1.00 \mathrm{E}-06$ & Infinity & Infinity \\
\hline $\operatorname{Cs} 134$ & $206 E+00$ & $3.36 \mathrm{E}-01$ & $8.66 \mathrm{E}-02$ & $9.00 E-07$ & $1.79 E+07$ & 4.85E-09 \\
\hline $\operatorname{Cs} 135$ & $3.00 \mathrm{E}+06$ & 2.31E-07 & $1.11 E-05$ & $1.00 \mathrm{E}-05$ & $5.00 \mathrm{E}-07$ & $2.21 E+01$ \\
\hline Cs 137 & $3.02 \mathrm{E}+01$ & $2.30 \mathrm{E}-02$ & $2.43 \mathrm{E}-01$ & $1.00 \mathrm{E}-06$ & 4.97E-07 & $4.89 E+05$ \\
\hline $\mathrm{Ba} 137 \mathrm{~m}$ & 4.85E-06 & $1.43 E+05$ & $2.30 E-01$ & $3.00 \mathrm{E}-06$ & Infinity & Infinity \\
\hline Cel41 & $8.90 \mathrm{E}-02$ & $7.79 \mathrm{E}+\infty 0$ & $1.65 \mathrm{E}-03$ & $3.00 \mathrm{E}-05$ & Infinity & Infinity \\
\hline Ce144 & $7.80 \mathrm{E}-01$ & 8.89E-01 & $1.46 \mathrm{E}-02$ & $3.00 \mathrm{E}-06$ & $5.87 E+31$ & 2.49E-34 \\
\hline $\operatorname{Pr} 144$ & 3.29E-05 & $2.11 E+04$ & $1.46 \mathrm{E}-02$ & $6.00 \mathrm{E}-04$ & Infinity & Infinity \\
\hline $\mathrm{Nd} 144$ & $2.10 E+15$ & $3.30 \mathrm{E}-16$ & $1.69 \mathrm{E}-10$ & $2.00 \mathrm{E}-09$ & $1.00 \mathrm{E}-10$ & 1.689 \\
\hline Pm147 & $2.62 E+00$ & $2.64 \mathrm{E}-01$ & $1.32 \mathrm{E}-02$ & $7.00 \mathrm{E}-05$ & $1.05 E+06$ & $1.26 \mathrm{E}-08$ \\
\hline To157 & $1.10 \mathrm{E}+02$ & $6.30 \mathrm{E}-03$ & $1.01 \mathrm{E}-10$ & $7.00 \mathrm{E}-04$ & 6.57E-05 & $1.54 E-06$ \\
\hline Tb158 & $1.80 \mathrm{E}+02$ & 3.85E-03 & 3.77E-10 & $2.00 \mathrm{E}-05$ & 1.47E-06 & $2.56 \mathrm{E}-04$ \\
\hline Hn175 & $1.92 \mathrm{E}-01$ & $3.62 \mathrm{E}+00$ & $1.43 E-03$ & $4.00 E-05$ & Infinity & Infinity \\
\hline Hn81 & $1.16 \mathrm{E}-01$ & $5.97 \mathrm{E}+00$ & $3.24 \mathrm{E}-03$ & 2.00E-05 & Infinity & Infinity \\
\hline Re187 & $4.10 E+10$ & $1.69 \mathrm{E}-11$ & $1.77 \mathrm{E}-11$ & $8.00 \mathrm{E}-03$ & $4.00 \mathrm{E}-04$ & 4.43E-08 \\
\hline Po209 & 3.71E-04 & $1.87 E+03$ & $1.28 \mathrm{E}-10$ & $2.00 \mathrm{E}-09$ & Infinity & Infinity \\
\hline Ra226 & $1.60 E+03$ & 4.33E-04 & $2.85 \mathrm{E}-04$ & $6.00 \mathrm{E}-08$ & 3.13E-09 & $9.10 E+04$ \\
\hline Th229 & $7.34 E+03$ & $9.44 E-05$ & 1.31E-10 & $2.00 \mathrm{E}-08$ & $1.01 E-09$ & $1.30 \mathrm{E}-01$ \\
\hline $\operatorname{Th} 230$ & $7.54 \mathrm{E}+04$ & $9.19 E-06$ & $1.72 \mathrm{E}-08$ & $1.00 \mathrm{E}-07$ & $5.00 \mathrm{E}-09$ & $3.44 \mathrm{E}+00$ \\
\hline Th232 & $1.41 E+10$ & $4.93 E-11$ & 8.17E-03 & $3.00 \mathrm{E}-08$ & $1.50 \mathrm{E}-09$ & $5.45 E+06$ \\
\hline $\mathrm{Pa} 231$ & $3.28 \mathrm{E}+04$ & $212 E-05$ & $1.02 \mathrm{E}-10$ & $6.00 \mathrm{E}-09$ & 3.01E-10 & 3.38E-01 \\
\hline U233 & $1.59 \mathrm{E}+05$ & 4.35E-06 & $2.31 E-07$ & $3.00 \mathrm{E}-07$ & $1.50 \mathrm{E}-08$ & $1.54 \mathrm{E}+01$ \\
\hline U234 & $245 E+05$ & $2.82 E-06$ & 5.37E-05 & $3.00 \mathrm{E}-07$ & $1.50 \mathrm{E}-08$ & $3.58 E+03$ \\
\hline U235 & $7.04 \mathrm{E}+08$ & $9.85 E-10$ & 2.54E-05 & $3.00 \mathrm{E}-07$ & $1.50 \mathrm{E}-08$ & $1.69 E+03$ \\
\hline U236 & $2.43 E+07$ & $2.85 E-08$ & $7.89 E-07$ & $3.00 \mathrm{E}-07$ & $1.50 \mathrm{E}-08$ & $5.26 E+01$ \\
\hline U238 & 4.47E+09 & $1.55 \mathrm{E}-10$ & $6.99 E-03$ & 3.00 E-07 & 1.50E-08 & $4.66 E+05$ \\
\hline Np237 & $2.14 E+06$ & $3.24 E-07$ & $1.67 E-07$ & $2.00 \mathrm{E}-08$ & $1.00 \mathrm{E}-09$ & $1.67 E+02$ \\
\hline Pu239 & $241 E+04$ & $2.87 E-05$ & $7.71 \mathrm{E}-06$ & $2.00 \mathrm{E}-08$ & $1.00 \mathrm{E}-09$ & $7.69 E+03$ \\
\hline $\mathrm{Pu} 240$ & $6.56 \mathrm{E}+03$ & $1.06 \mathrm{E}-04$ & $1.89 \mathrm{E}-06$ & $2.00 \mathrm{E}-08$ & $1.01 E-09$ & $1.87 E+03$ \\
\hline $\mathrm{Pu} 242$ & $3.76 E+05$ & $1.84 \mathrm{E}-06$ & 4.65E-07 & $2.00 \mathrm{E}-08$ & $1.00 \mathrm{E}-09$ & $4.65 E+02$ \\
\hline Am241 & $4.32 \mathrm{E}+02$ & $1.60 \mathrm{E}-03$ & $3.06 \mathrm{E}-05$ & $2.00 \mathrm{E}-08$ & $1.17 \mathrm{E}-09$ & $2.61 E+04$ \\
\hline Am243 & $7.38 \mathrm{E}+03$ & 9.39E-05 & $1.06 \mathrm{E}-08$ & $2.00 \mathrm{E}-08$ & $1.01 \mathrm{E}-09$ & $1.05 E+01$ \\
\hline $\mathrm{Cm} 248$ & $3.40 E+05$ & $2.04 \mathrm{E}-06$ & 4.70E-07 & $5.00 \mathrm{E}-09$ & $2.50 \mathrm{E}-10$ & $1.88 \mathrm{E}+03$ \\
\hline
\end{tabular}

${ }^{a}$ Curies per cubic meter.

bIngested water derived concentration guidelines, NRC 1989. 
A.3 REFERENCES

DOE, see U.S. Department of Energy.

Domenico, P. A. and F. W. Schwartz, 1990, Physical and Chemical Hydrogeology, John Wiley and Sons, New York, New York.

Federal Register, 1993, 58 FR 244, "Standards for Protection Against Radiation; Removal of Expired Materials," U.S. Nuclear Regulatory Commission, December 22, 1993, p. 67659.

NRC, see U.S. Nuclear Regulatory Commission.

Seitz, R. R. and D. C. Kosher, 1993, "On Establishing Waste Concentration Limits for Low-Level Radioactive Waste Disposal," Proceedings of the Symposium on Waste Management, Tucson, Arizona.

U.S. Department of Energy (DOE), 1992, Integrated Data Base for 1992: U.S. Spent Fuel and Radioactive Waste Inventories, Projections, and Characteristics, DOE/RW-006, Rev. 8, U.S. Department of Energy, Washington, D.C.

U.S. Nuclear Regulatory Commission (NRC), 1989, "Standards for Protection Against Radiation," Title 10, Code of Federal Regulations, Part 20 (10 CFR 20), Appendix B, U.S. Nuclear Regulatory Commission, Washington, D.C.

AL04-94/WP/EGG:R3273-A

A-6 